TiY de Albuquerque Maranhão Reis

\title{
A Terapia Ocupacional Social: análise da produção científica do estado de São Paulo
}

Dissertação apresentada à Faculdade de Medicina da Universidade de São Paulo para obtenção do título de Mestre em Ciências

Área de concentração: Movimento, Postura e Ação Humana

Orientadora: Profa. Dra. Denise Dias Barros

São Paulo

2008 
Ao meu eterno companheiro de caminho e aos companheiros com os quais ele me dá a alegria de conviver... 


\section{Sumário}

Resumo

Summary

1. Introduzindo e definindo o universo do estudo...................................... 1

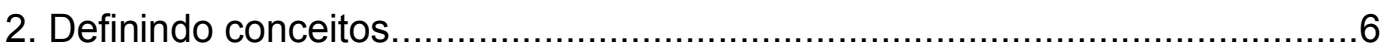

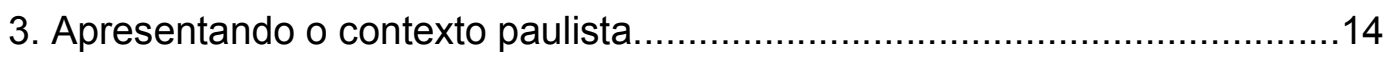

4. O debate da terapia ocupacional social nos congressos brasileiros............20

4.1 Intercessões e diálogos entre áreas - as diferenças surgem

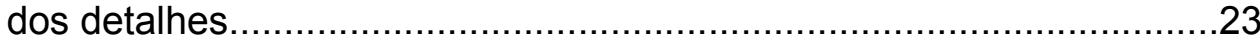

4.2 A Terapia Ocupacional Social em cada congresso............................32

5. A constituição do campo da terapia ocupacional social e seus autores........48

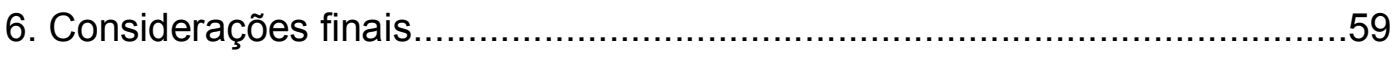

Anexo A - Lista com os 105 trabalhos selecionados nos CBTO.................... 64

Anexo B - Histórico da Produção Bibliográfica de Autores Paulistas

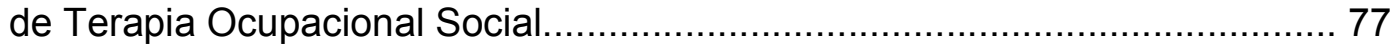

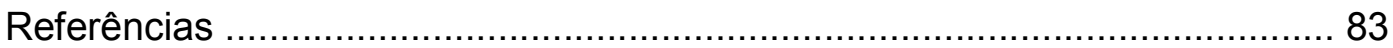




\section{Resumo}

Reis TAM. A Terapia Ocupacional Social - análise da produção científica do estado de São Paulo [dissertação]. São Paulo: Faculdade de Medicina, Universidade de São Paulo; 2008.

Este estudo analisa o processo de consolidação da Terapia Ocupacional Social, com base na produção científica do estado de São Paulo. Tal campo, criado nos anos 1970, desenvolveu-se a partir de debates nas instituições de ensino de São Paulo, cuja produção tem sido fundamental para seu desenvolvimento no Brasil, com significativas contribuições no âmbito teórico e prático. Como fontes, utilizaram-se os trabalhos apresentados nos seis últimos Congressos Brasileiros de Terapia Ocupacional, bem como a bibliografia sobre o tema. A análise evidenciou as questões levantadas através desse campo, identificou seus principais autores e suas contribuições: o desenvolvimento de tecnologias para lidar com as questões sociais vinculadas à ação junto às(aos) pessoas/grupos em processo de rupturas de redes sociais.

DESCRITORES: Terapia ocupacional/tendências; Assistência social; Grupo social; Congressos; Brasil; Bibliografia; Terapia ocupacional/métodos; Terapia ocupacional/educação. 


\section{Summary}

Reis TAM. Social Occupational Therapy - analysis of the scientific production from the State of São Paulo [dissertation]. São Paulo: Faculty of Medicine, University of São Paulo; 2008.

This study analyses the Social Occupational Therapy consolidation process based on the scientific production from the state of São Paulo, in whose educational institutions such field, created in the $1970_{s}$, was developed by means of several debates. This gave rise to a fundamental production for its development in Brazil, with significant theoretical and practical contributions. The works presented in the six last Brazilian Congresses of Occupational Therapy, as well as the existent bibliography on the subject were used as sources of research. The analysis outlined the questions raised by this field, identified its main authors and their contributions: the development of technologies to deal with social issues related to procedures concerning people/groups going through processes of social net rupture.

DESCRIBERS: Occupational Therapy/trends; Social assistance; Social group; Congresses; Brazil; Bibliography production; Occupational Therapy/education. 


\section{Introduzindo e definindo o universo do estudo}

O surgimento e a expansão da Terapia Ocupacional Social têm nos congressos brasileiros, nas publicações em periódicos, livros e coletâneas fontes fundamentais para a apreensão de sua formação como campo específico.

De forma resumida, pode-se dizer que este estudo teve como finalidade conhecer:

- A produção científica de Terapia Ocupacional Social no Brasil, notadamente em São Paulo, mediante pesquisa dos trabalhos apresentados nos Congressos Brasileiros de Terapia Ocupacional (CBTOs) e também das publicações em literatura especializada

- Os autores que publicaram sobre Terapia Ocupacional Social, bem como as principais questões abordadas atualmente nesse campo.

Os CBTOs forneceram dados empíricos por meio dos quais foi possível identificar os autores, suas instituições e os temas/campos dos trabalhos apresentados. Dessa maneira, foram selecionados e analisados trabalhos com a temática em estudo apresentados nos últimos seis CBTOs. Evidenciou-se a existência de estreita correlação entre práticas de ensino e de extensão nas instituições de ensino superior (IES) paulistas e o desenvolvimento da Terapia Ocupacional Social, assim como o expressivo ritmo de crescimento da área nos últimos anos. 
Verificou-se, por meio do mapeamento das instituições de ensino no país, que o estado de São Paulo concentra grande parte das titulações docentes e das publicações. ${ }^{1,2} \mathrm{O}$ corpo de conhecimento da Terapia Ocupacional provém significativamente de autores dos quadros das IES do estado de São Paulo. Ele é também o estado que apresenta o maior número de cursos, aproximadamente $41 \%$ do total oferecido no Brasil, com $37,5 \%$ das graduações mais antigas e consolidadas. ${ }^{3}$ Segundo dados do Ministério da Educação referentes ao período de 1991 a 2004, verificou-se um crescimento de cursos maior que nos demais estados da federação, incluindo o estado de Minas Gerais, que também possui expressivo número de cursos:

\author{
Minas Gerais e São Paulo, que ofereciam \\ respectivamente dois e quatro cursos [considerando \\ período compreendido entre 1991 e 2004], tiveram uma \\ ampliação significativa para seis e treze cursos \\ respectivamente, evidenciando que foi no estado de \\ São Paulo que mais se aumentou o número de cursos \\ no país. ${ }^{4}$ [grifo nosso]
}

A formação teórica e prática de terapeutas ocupacionais constitui um elemento importante na busca de fontes para a discussão da formação do campo da Terapia Ocupacional Social. Os docentes e pesquisadores das instituições paulistas formam parte significativa do cenário atual desse campo devido à sua produção acadêmica e, também, aos programas de extensão e serviços à comunidade que desenvolvem. Procurou-se, assim, conhecer as IES 
do estado de São Paulo para identificar a presença da discussão explícita (disciplinas) a cerca do social.

Abordar de que forma vem se processando o ensino do campo da Terapia Ocupacional Social no Brasil poderia ser um meio de verificação de seu desenvolvimento, mas para isso seria necessária outra pesquisa.

A análise dos trabalhos dos CBTOs revelou a predominância de profissionais/autores do estado de São Paulo na produção em Terapia Ocupacional Social e permitiu conhecer a influência que esse campo vem recebendo do meio universitário, dado que a maioria dos trabalhos com essa filiação temática provinham de iniciativas ligadas ao ensino, à pesquisa ou à extensão em IES.

Mediante a análise dos trabalhos dos congressos foi possível, ainda, identificar os autores e as obras considerados de referência para a Terapia Ocupacional Social. No caso dos dados provenientes dos CBTOs, além de receberem análise qualitativa, foram submetidos a tratamento estatístico para a definição de seu comportamento em cada evento analisado e estabelecimento dos índices de crescimento dos campos comparados (produção de Terapia Ocupacional em geral e produção de Terapia Ocupacional Social).

O levantamento da produção científica em periódicos e livros corroborou os dados dos CBTOs com relação à predominância de autores do estado de São Paulo e a expansão do campo relacionada sobretudo a programas de extensão universitária.

A análise dos dados documentais obtidos foi de natureza qualitativa e interpretativa. Seu corpus, que segundo consta no Dicionário 
Aurélio Conjunto é o "conjunto de documentos, dados e informações sobre determinada matéria", ${ }^{5}$ foi então, composto pelos dois conjuntos de dados mencionados, ou seja: trabalhos de Terapia Ocupacional Social publicados pelos CBTOs e produção científica dos autores do campo social.

Com relação à apreciação dos trabalhos publicados nos CBTOs, convém esclarecer que nos V, IX e X Congressos Brasileiros de Terapia Ocupacional foram encontrados mais subsídios para análise, pois os estes publicaram trabalhos completos e não somente resumos. Porém, cabe ressaltar que, diferente do material encontrado no formato de artigo e principalmente naqueles em formato de dissertação, em que os autores dispõem de maior espaço para expressar suas idéias, os trabalhos escritos para congressos (a exceção daqueles em formato de pôster) são muitas vezes complementares às exposições orais de seus autores.

Desse modo, ainda que haja uma diversidade no formato das fontes documentais, o que de certa forma influenciou no processo de análise, elas formaram um universo de dados que permitiu desvendar os grupos sociais, as temáticas, as metodologias e os objetivos das intervenções presentes nos trabalhos de congressos ou nas publicações, evidenciando o desenvolvimento da reflexão e a dinâmica das práticas no campo da Terapia Ocupacional Social.

O presente estudo tem como intuito apresentar as reflexões oriundas da pesquisa realizada, sem a intenção de esgotar as múltiplas perspectivas de análise que possam ainda ser elaboradas, sabendo que a argumentação aqui construída é uma dentre outras possibilidades de ver e interpretar os trabalhos utilizados como fonte. Cabe acrescentar que se trata de 
estudo interpretativo e, portanto, de reflexões da autora, que podem não estar de acordo com a opinião dos autores dos trabalhos analisados.

Como desdobramento do processo de pesquisa, idealizou-se um banco de textos de Terapia Ocupacional Social. A proposta de organização desse banco de dados encontra-se no CD-ROM em anexo, que contém referências de todos os trabalhos de Terapia Ocupacional Social publicados nos seis eventos analisados. Ele permite demonstrar o acúmulo de pesquisas e ações que vem sendo construído na história da Terapia Ocupacional Social. A organização do CD-ROM tem por objetivo futuro contribuir com tal processo, pois se pretende alimentar o banco de dados com artigos, dissertações e teses elaborados no país, mediante prévia consulta e permissão de seus autores. 


\section{Definindo conceitos}

O que está sendo considerado nesse trabalho como campo social? Quais reflexões e conceitos possibilitaram a constituição da chamada Terapia Ocupacional Social? São questões introduzidas aqui a fim propiciar a explicitação das bases conceituais das análises presentes nesta dissertação.

A noção de campo proposta por Pierre Bourdieu ${ }^{6-9}$ constitui um dos pilares da argumentação. Segundo o autor, o campo forma um conjunto de saberes e de práticas específicos e diferenciados de outros campos construídos historicamente e em contextos definidos a partir de dinâmicas de poder e do entrecruzamento dos agentes desse campo. Nesse sentido, a Terapia Ocupacional Social pode ser compreendida como referida à produção de intelectuais, em sua maioria do meio universitário, que foram construindo o discurso e a práxis do campo social. Nesse processo, houve o rompimento do paradigma que vincula a profissão ao binômio saúde-doença, inscrito nas práticas histórias da reabilitação, e a formação de habitus próprio. Entendendo por habitus

[...] um sistema de disposições duráveis e transponíveis que, integrando todas as experiências passadas, funciona em cada momento como uma matriz de percepções, apreciações e ações e torna possível cumprir tarefas infinitamente diferenciadas, graças à 
transferência analógica de esquemas adquiridos numa prática anterior. $^{10}$

A preocupação com as dinâmicas sociais exigiu o diálogo com as Ciências Sociais, o que gerou uma articulação mais orgânica com a Terapia Ocupacional. Como resultante do entrecruzamento de forças de coesão (manutenção da doxa e, portanto, da vocação inicial da profissão) e de cisão (representado pela heresia e, por isso, pelo esforço de expansão da Terapia Ocupacional para além de seus horizontes conhecidos e pactuados), produziuse um campo que extrapolou os domínios de práticas existentes. As antinomias produzidas parecem ter sido (mesmo que parcialmente) superadas e as diferenciações puderam ser incorporadas pelo campo conjuntural maior que é o da Terapia Ocupacional no decorrer dos últimos 20 anos aproximadamente. Bourdieu enfatiza que a

estrutura do campo é um estado da relação de força entre os agentes ou as instituições engajadas na luta ou, se preferirmos, da distribuição do capital específico que, acumulado no curso das lutas anteriores, orienta as estratégias ulteriores. ${ }^{11}$

O conceito de campo social, ou espaço social, a partir do qual a Terapia Ocupacional vem problematizando sua ação também pode ser compreendido com apoio de Pierre Bourdieu, para quem o campo social forma um universo constituído por forças e posições de dominação, portanto, por 
pessoas ou grupos sociais dominantes e dominados que vivenciam papéis diferenciados no interjogo de sua participação na vida cotidiana. Essas relações se dão em uma dinâmica permanente e de maneira multidimensional, e são atravessadas pelos contextos histórico e cultural em que a sociedade é produzida, não podendo, por isso, ser compreendidas isoladamente desses parâmetros.

O estudo das desigualdades produzidas nas dinâmicas relacionais, bem como dos papéis e das atuações dos grupos sociais, o modo como se organizam, seus habitus, suas relações internas (intragrupais, comunitárias) e externas com outros grupos e todas as questões que daí decorrem estão no bojo do que chamamos aqui de campo social. Trata-se de objeto de investigações sob perspectivas distintas de campos do conhecimento como a Sociologia, a Antropologia, a Ciência Política e a História.

A Terapia Ocupacional Social empreende, pois, meios e tecnologias oriundas de seu corpo de conhecimento, a saber: a habilidade técnica de manejo de grupos, o conhecimento das dinâmicas de interações grupais, da relação do homem com seu fazer e os diferentes papéis sociais que o fazer humano origina em cada grupo social ou comunidade. Ela estabelece, assim, o diálogo com as Ciências Sociais a fim de lidar de forma criativa com o enfrentamento das questões sociais (desigualdades, pobreza, discriminação, violência e subjugação) presentes na sociedade brasileira e que estão bastante relacionadas à falta de acesso a direitos humanos fundamentais e variadas formas de discriminação sofridas por grupos populacionais diversos.

O diálogo com as Humanidades permitiu compreender os processos históricos das situações descritas acima, bem como as 
características culturais e os modos de organização das diferentes populações que tem sido alvo da ação de terapeutas ocupacionais sociais. Assim, desenhou-se estratégias de intervenção pensadas de maneira contígua à realidade cotidiana e aos valores de cada um desses grupos.

\begin{abstract}
A importância atribuída às ações transdisciplinares e à necessidade de incorporar conhecimentos sócioantropológicos aos conhecimentos específicos permitiram que terapeutas ocupacionais contribuíssem para o entendimento e o desenvolvimento de metodologias de abordagens individuais e coletivas em campos distanciados da saúde tais como a assistência social, os trabalhos comunitários, o meio ambiente e as relações interculturais, entre outros. ${ }^{12}$
\end{abstract}

Diversos autores como Paulo Freire, Robert Castel e Norbert Elias e os conteúdos trabalhados por eles vêm sendo utilizados na elaboração das tecnologias de atendimento da Terapia Ocupacional Social. Conceitos como dialogicidade, cidadania, habitus, vulnerabilidade social, redes sociais e desfiliação foram sendo incorporados, conforme movimento apontado no trecho acima, como chaves de compreensão das dinâmicas socioculturais com as quais os terapeutas ocupacionais se deparam no campo social. Porém, um conceito-chave nesse processo é o de questão social desenvolvido por Castel, ${ }^{13}$ que a identifica como 
[...] uma dificuldade central, a partir da qual uma sociedade se interroga sobre sua coesão e tenta conjurar o risco de sua fratura. É, em resumo, um desafio que questiona a capacidade de uma sociedade de existir como um todo, como um conjunto ligado por relações de interdependência. $^{14}$

O ressurgimento do social colocado como questão a ser trabalhada e considerada de forma específica e não em termos de contextos mais amplos e genéricos se deu, sobretudo, impulsionada pela sociologia francesa a partir da década de 1990 e, desde então, vem trazendo subsídios para a compreensão das situações de injustiça social, das relações de dominação e de desigualdades que se encontram no bojo de diversas sociedades, além disso, contribuiu para a identificação dos grupos e populações que se encontram no centro dessas problemáticas e cujas demandas serão consideradas pelos terapeutas ocupacionais sociais.

Finalmente, cabe acrescentar as articulações que se fizeram possíveis a partir do conceito de habitus e suas implicações para a terapia ocupacional social.

Bourdieu, ao desenvolver o conceito de habitus, segundo apontado por Noronha e Rocha, ${ }^{15}$ vai de encontro ao pensamento/paradigma estruturalista. O estruturalismo entendia os comportamentos e ações dos indivíduos como sendo marcadamente influenciados por determinismos das sociedades a qual pertenciam, o que, para alguns sociólogos, incluindo 
Bourdieu, estabelecia uma dicotomia entre as concepções de indivíduo e de sociedade.

Ainda segundo Noronha e Rocha,$^{15}$ o conceito de habitus permite compreender as relações e interpenetrações entre os conceitos de indivíduo e de sociedade. Dessa maneira, torna-se operativo para a Terapia Ocupacional Social, na medida em que é o conceito utilizado para compreender de que maneira os indivíduos, enquanto atores sociais, e sua historicidade recebem influências da cultura e da sociedade, e, em contrapartida, de que forma a sociedade e os grupos sociais refletem as intervenções e os conflitos individuais.

Outro autor que também contribuiu sobremaneira com a noção de dialogicidade entre os conceitos de indivíduo e sociedade - e por isso utilizado instrumentalmente pela Terapia Ocupacional Social no entendimento dos processos de constituição do indivíduo na sociedade e desta por seus indivíduos - é Norbert Elias. A esse respeito, o autor coloca:

Normalmente imaginamos o ser humano, na atualidade, como dotado de diversos compartimentos psíquicos. Estabelecemos distinções entre "mente" e "alma", "razão" e "sentimento", "consciência" e "instinto" ou "ego" e "ide". Mas a nítida diferenciação das funções psíquicas evocada por essas palavras não é, vale reiterar, algo simplesmente dado por natureza. Ela só ocorre no ser humano quando ele cresce - criança - num grupo, numa sociedade de pessoas. Não ocorre como o crescimento 
físico, por exemplo, em decorrência de um mecanismo natural herdado, mas emerge do entrelaçamento das "naturezas" de muitas pessoas. [...] Ela é produto de um processo sócio-histórico, de uma transformação da estrutura da vida comunitária. ${ }^{16}$

Elias aponta ainda, que seria improdutivo considerar os conceitos de indivíduo e sociedade em oposição mútua ou em uma relação unidirecional de causa e efeito:

[...] os modos de pensamento e discurso que levam à utilização dos termos "indivíduo" e "sociedade" como se eles se referissem a duas entidades distintas e independentes - sem excluir a idéia de sua "relação recíproca" - são muito elementares e não particularmente adequados. ${ }^{17}$

O entendimento a respeito das formas como indivíduos e sociedades vão se estruturando e transformando mutuamente e a compreensão de que os processos de constituição e desenvolvimento individuais e sociais ocorrem de maneira indissociável contribuíram também para a definição de que o objeto da ação do terapeuta não é uma questão social emergente, e sim de demandas reais dos indivíduos e dos grupos sociais a que pertencem, demandas essas que se inscrevem, freqüentemente, em questões sociais historicamente definidas e que possibilitaram tanto 0 
desenvolvimento de intervenções e projetos de natureza individual quanto de âmbito coletivo ou comunitário, entendidas como uma necessária complementaridade. 


\section{Apresentando o contexto paulista}

A fim de se contextualizar a importância do estado de São Paulo na produção científica de Terapia Ocupacional Social, entende-se como passo inicial demonstrar a concentração de cursos de graduação existentes no estado e também a distribuição do ensino específico do campo social nas instituições de ensino superior (IES) paulistas.

Mediante levantamento realizado pelo Instituto Nacional de Estudos e Pesquisas Educacionais Anísio Teixeira (INEP), observou-se que o número de graduações em Terapia Ocupacional apresentou grande crescimento nas últimas décadas, fato que acompanhou a política de expansão do ensino superior no país, notadamente no ramo privado. Esse crescimento se acentuou a partir da década de 1980, conforme ilustrado no Gráfico 1. Em 1983, por exemplo, havia um total de 10 cursos de graduação em Terapia Ocupacional no país. Ao passo que em outubro de 2008 já havia 63 cursos.

É importante apontar que o número de cursos de terapia ocupacional vem sendo alterado a intervalos de tempo cada vez menores. Dessa forma, optou-se por trabalhar com percentuais, por tratar-se de valores que sofrem menor alteração que os valores absolutos. Convém esclarecer também que os valores aqui presentes dizem respeito ao final de 2007 , período em que foi concluído o levantamento dos dados relativos à distribuição desses cursos no país. 
Gráfico 1 - Número de cursos de Terapia Ocupacional criados, segundo década de criação

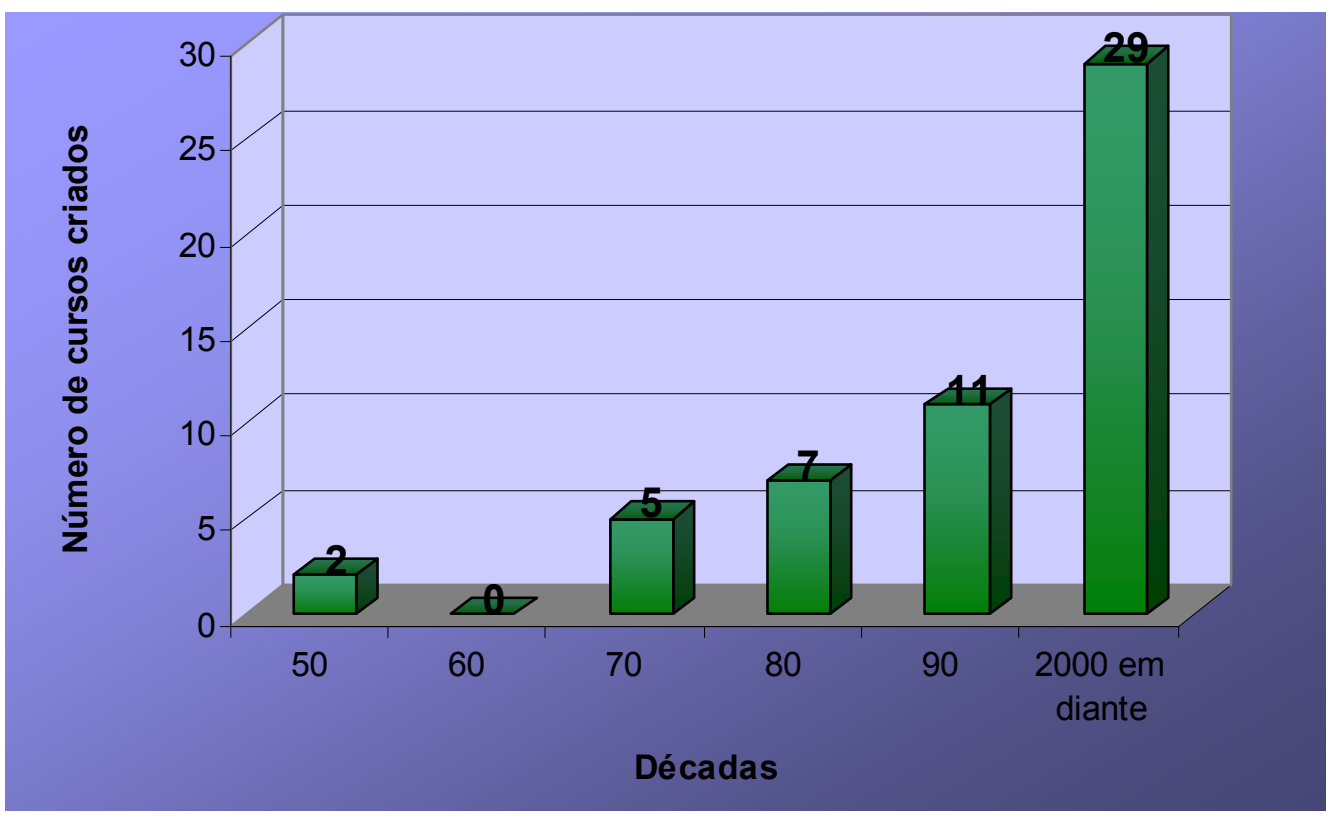

FONTE: Instituto Nacional de Estudos e Pesquisas Educacionais Anísio Teixeira (INEP)

Segundo dados do INEP, ${ }^{18}$ em 2007 os cursos estavam distribuídos geograficamente da seguinte maneira: $65 \%$ localizados na região Sudeste, $17 \%$ na região nordeste, $11 \%$ na região Sul, $6 \%$ na região Centrooeste e $2 \%$ na região Norte do país, conforme ilustrado no Gráfico 2. Nele pode-se notar a concentração substancial de instituições de ensino na região Sudeste responsáveis por 34 cursos dentre os 54 existentes no país na ocasião da última verificação. Naquele momento, somente no estado de São Paulo localizavam-se aproximadamente $63 \%$ dos cursos existentes na região sudeste. 
Gráfico 2 - Distribuição percentual de cursos de Terapia Ocupacional em cada região do Brasil

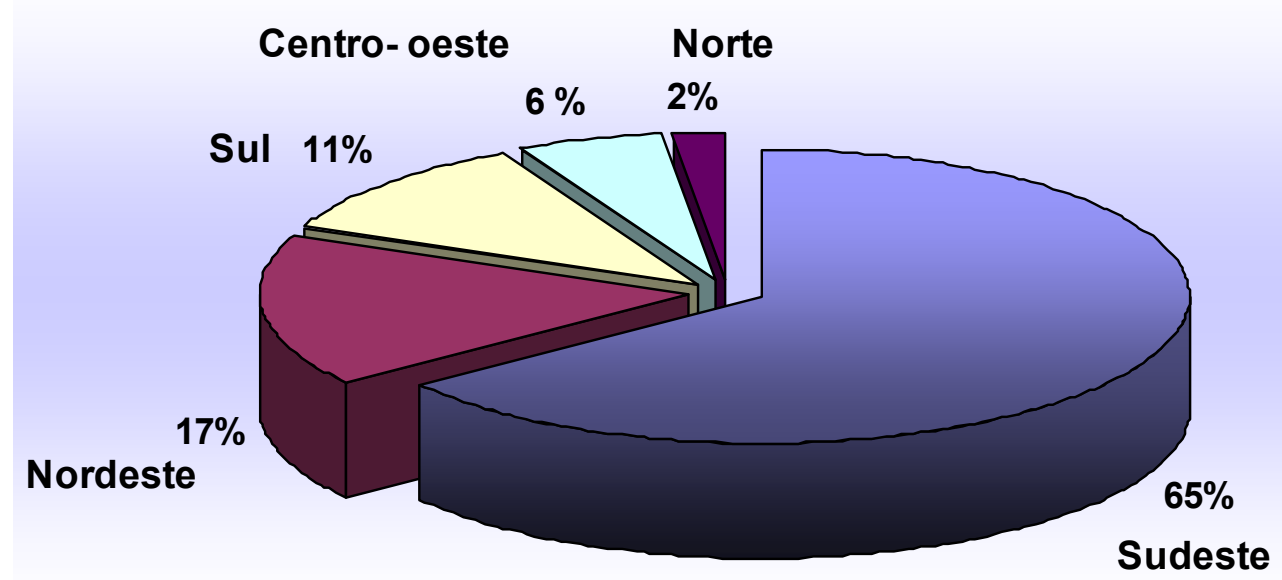

FONTE: Instituto Nacional de Estudos e Pesquisas Educacionais Anísio Teixeira (INEP)

A concentração de cursos no estado de São Paulo somada à elevada concentração de pesquisadores nessa região fazem do estudo da produção científica do estado um parâmetro importante para compreender o desenvolvimento de novos campos na Terapia Ocupacional.

A fim de conhecer a distribuição do ensino de Terapia Ocupacional Social no estado de São Paulo foram consideradas as instituições paulistas que criaram graduações de Terapia Ocupacional até 2003, ou seja, cursos que já possuíam o ciclo completo de formação e que, portanto, já tivessem formado pelo menos uma turma.

Foi, então, apurado um total de 12 cursos, conforme consta na Tabela 1. As IES paulistas que possuem ensino de Terapia Ocupacional Social foram identificadas através do conteúdo publicado na rede mundial de computadores em seus respectivos portais eletrônicos, nos quais constam as grades curriculares e ementário de disciplinas. 
Tabela 1 - Instituições de ensino superior do estado de São Paulo que oferecem o curso de Terapia Ocupacional com ano de criação até 2003, segundo localização, categoria administrativa, data de criação do curso e presença de disciplina específica de Terapia Ocupacional social em 2008

\begin{tabular}{|c|c|c|c|c|}
\hline INSTITUIÇÃO & CIDADE & $\begin{array}{c}\text { CATEGORIA } \\
\text { ADMINISTRATIVA }\end{array}$ & $\begin{array}{l}\text { DATA DE } \\
\text { CRIAÇÃOO }\end{array}$ & $\begin{array}{l}\text { DISCIPLINA } \\
\text { ESPECÍFICA }\end{array}$ \\
\hline$U S P-S P^{1}$ & $\begin{array}{c}\text { São } \\
\text { Paulo }\end{array}$ & Público/ Estadual & 1/1/1958 & Sim \\
\hline PUCCamp $^{2}$ & Campinas & Privada & $1 / 3 / 1977$ & $\left({ }^{*}\right)$ \\
\hline UFSCar ${ }^{3}$ & $\begin{array}{l}\text { São } \\
\text { Carlos }\end{array}$ & Público/ Federal & 9/7/1978 & Sim \\
\hline UNISALESIANO ${ }^{4}$ & Lins & Privada & $3 / 12 / 1980$ & Sim \\
\hline UNIVAP $^{5}$ & Jacareí & Privada & $11 / 8 / 1997$ & Não \\
\hline Cusc $^{6}$ & $\begin{array}{c}\text { São } \\
\text { Paulo }\end{array}$ & Privada & 2/2/1998 & Não \\
\hline UNISO $^{7}$ & Sorocaba & Privada & $2 / 2 / 1998$ & Sim \\
\hline USC $^{8}$ & Bauru & Privada & $8 / 2 / 1999$ & $\left({ }^{*}\right)$ \\
\hline UNIMONTE $^{9}$ & Santos & Privada & $7 / 2 / 2000$ & $\left({ }^{*}\right)$ \\
\hline CEUCLAR ${ }^{10}$ & Batatais & Privada & $13 / 8 / 2001$ & Sim \\
\hline USP - RP ${ }^{11}$ & $\begin{array}{l}\text { Ribeirão } \\
\text { Preto }\end{array}$ & Público/ Estadual & $1 / 1 / 2002$ & Sim \\
\hline UNESP $^{12}$ & Marília & Público/ Estadual & $4 / 8 / 2003$ & $\left({ }^{*}\right)$ \\
\hline
\end{tabular}

FONTE: USP-SP, PUCCamp, UFSCar, UNISALESIANO, UNIVAP, CUSC, UNISO, USC, UNIMONTE, CEUCLAR, USP-RP, UNESP

$\left.{ }^{*}\right)$ Grades curriculares não divulgadas nos sites das referidas IES

${ }^{1}$ Universidade de São Paulo - São Paulo

${ }^{2}$ Pontifícia Universidade Católica de Campinas

${ }^{3}$ Universidade Federal de São Carlos

${ }^{4}$ Centro Universitário Católico Salesiano Auxilium

${ }^{5}$ Universidade do Vale do Paraíba

${ }^{6}$ Centro Universitário São Camilo

${ }^{7}$ Universidade de Sorocaba

${ }^{8}$ Universidade do Sagrado Coração

${ }^{9}$ Centro Universitário Monte Serrat

${ }^{10}$ Centro Universitário Claretiano

${ }^{11}$ Universidade de São Paulo - Ribeirão Preto

12 Universidade Estadual Paulista Júlio de Mesquita Filho

Portanto, o levantamento realizado em fevereiro de 2008 apontou para o fato de que aproximadamente $50 \%$ das graduações do estado de São 
Paulo possuem disciplina específica sobre Terapia Ocupacional Social (Gráfico

3), seja no formato teórico, seja como um módulo prático ou ambos.

Gráfico 3 - Distribuição percentual dos cursos de Terapia Ocupacional do estado de São Paulo, segundo presença de disciplina específica de Terapia Ocupacional Social em 2008

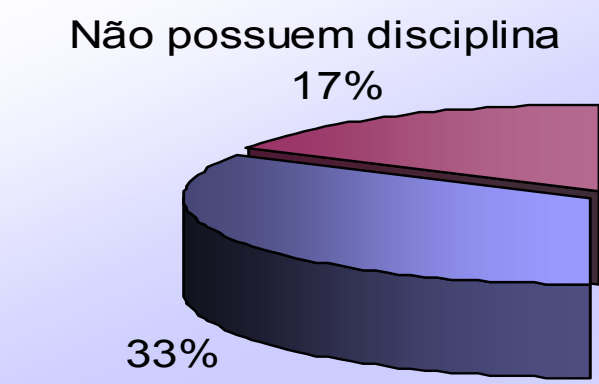

Não informado

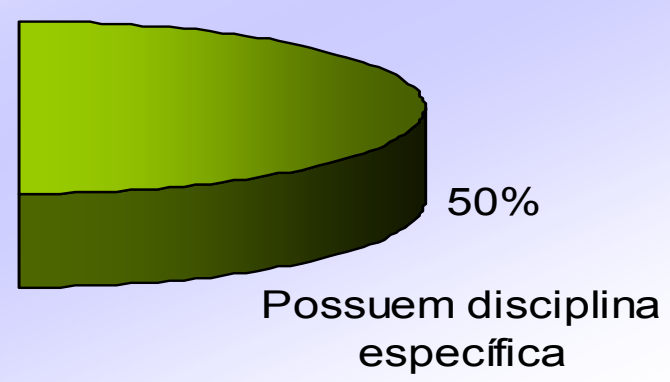

específica

FONTE: USP-SP, PUCCamp, UFSCar, UNISALESIANO, UNIVAP, CUSC, UNISO, USC, UNIMONTE, CEUCLAR, USP-RP, UNESP

Examinado as ementas de disciplinas, foi possível perceber também que nas instituições mais antigas a disciplina específica foi criada posteriormente à criação do curso, porém constatou-se que existem cursos que incorporaram o ensino de Terapia Ocupacional Social desde o início de seu funcionamento.

O levantamento de dados tornou possível perceber que há no estado de São Paulo a conjugação de dois fatores: a mais alta concentração de cursos, em números absolutos do país (atualmente 63) e também a presença das mais antigas e consolidadas graduações em terapia ocupacional. Além de constituir um centro formador, o estado de São Paulo possui o maior número de terapeutas ocupacionais doutores, e suas instituições de ensino são responsáveis por grande parte da produção no cenário nacional, conforme 
evidenciaram os estudos de Lancman, ${ }^{1}$ Emmel e Lancman, ${ }^{3}$ Barros e Oliver. ${ }^{19}$ Por tais razões, este estudo, ainda que referido à produção científica do estado de São Paulo, pode contribuir para a compreensão do campo social na terapia ocupacional brasileira. 


\section{O debate da terapia ocupacional social nos congressos} brasileiros

No presente capítulo pretende-se descrever a constituição do campo social na Terapia Ocupacional brasileira a partir do mapeamento dos trabalhos apresentados nos últimos seis Congressos Brasileiros de Terapia Ocupacional (CBTO) realizados em Belo Horizonte, Minas Gerais (1997); Águas de Lindóia, São Paulo (1999); Porto Alegre, Rio Grande do Sul (2001); Foz do Iguaçu, Paraná (2003); Recife, Pernambuco (2005); Goiânia, Goiás (2007).

Tais eventos promovem o encontro de experiências e/ou reflexões oriundas do ensino (meio acadêmico) e do cotidiano de trabalho de diversos terapeutas ocupacionais (mercado de trabalho), além de representarem parte importante da produção científica da área, dado que esta não se encontra ainda totalmente consolidada no cenário científico e acadêmico brasileiro.

Desse modo, ao pesquisar as publicações em congressos, é possível tomar a produção científica da terapia ocupacional brasileira em sua abrangência e conjunto, além de mapeá-la em termos de suas diferentes áreas de atuação e também distribuição geográfica no país. Por essas razões, os CBTOs constituem-se em referências relevantes para a compreensão do desenvolvimento da Terapia Ocupacional, sua historicidade e diversificação em novos campos. 
Os materiais utilizados como fonte foram os anais dos

Congressos Brasileiros de Terapia Ocupacional, impressos e em CD-ROM, partindo do quinto até o décimo CBTO.*

Foi também verificada a procedência dos trabalhos relacionados ao campo social, a fim de levantar dados sobre sua distribuição e crescimento no país.

Ao longo do levantamento realizado, percebeu-se um aprimoramento cada vez maior na organização dos eventos, bem como o crescimento expressivo do número de trabalhos apresentados e a diversificação de temáticas. Tal crescimento demonstra tanto a afirmação dos congressos como um dos principais espaços para onde convergem trabalhos de terapeutas ocupacionais de todo o país, quanto o esforço de sistematização das práticas e reflexões desenvolvidas por esses profissionais, revelando também o processo de consolidação da profissão ao longo das últimas décadas no cenário profissional e acadêmico brasileiro.

Muitas varreduras foram necessárias, a fim de identificar e distinguir as diferentes afinidades temáticas e abordagens entre os trabalhos, 0 que permitiu um aprofundamento do panorama de análise e o detalhamento dos critérios. Assim, foram selecionados(as):

1. Trabalhos ou estudos que ocorressem em programas e/ou instituições públicas ou conveniadas da assistência social, da justiça, da educação e/ou da cultura;

\footnotetext{
* Convém salientar que o formato escolhido por cada evento para compilar os trabalhos nele apresentados interferiu na sua análise, já que em alguns eventos houve a publicação somente de resumos dos trabalhos, como caso do VI, VII e VII CBTO, ao passo que os demais publicaram versões mais ampliadas dos trabalhos em seus anais. São eles o V CBTO (Belo horizonte), o IX CBTO (Recife) e o X CBTO (Goiânia).
} 
2. Reflexões sobre a responsabilidade social e o papel éticopolítico dos terapeutas ocupacionais;

3. Trabalhos que retratam a constituição do campo social na terapia ocupacional e seus pressupostos teóricometodológicos;

4. Questões relativas ao ensino da terapia ocupacional no campo social;

5. Discussões e análises de programas e projetos de intervenção universitária voltados para a participação social e que atuem em contextos comunitários ou territoriais, cuja população-alvo não seja definida exclusivamente pela problemática de saúde/doença, por processos de tratamento ou abordagens desenvolvimentistas;

6. Discussões e análises de programas sociais e/ou culturais de organizações não-governamentais (ONGs), associações, ou universidades voltados a grupos, pessoas e/ou comunidades desfavorecidas social e economicamente;

7. Discussões e análises de programas sociais e/ou culturais de ONGs, associações ou universidades voltados a grupos, pessoas e/ou comunidades desfavorecidas social e economicamente e marcados por práticas culturais diferenciadas; 
8. Trabalhos ou pesquisas que se destinavam à análise de políticas públicas e/ou redes de atenção a populações em situação de vulnerabilidade social;

9. Discussões e análises de programas sociais destinados à profissionalização ou ao acesso ao mercado de trabalho de populações em situação de risco ou vulnerabilidade social e cuja caracterização, como grupo social, não se dê em função de problemática de saúde.

Foram excluídos os trabalhos que apresentavam abordagens clínicas ou que fossem centrados em questões envolvendo saúde, processos de tratamento e reabilitação. Também não foram considerados os textos que traziam propostas educativas na área do desenvolvimento neuropsicomotor ou da aquisição de habilidades. A seguir, demonstra-se o processo de análise a partir de alguns trabalhos trazidos a título de exemplo.

\subsection{Intercessões e diálogos entre áreas - as diferenças surgem dos detalhes}

No levantamento realizado, os trabalhos foram classificados segundo a análise proposta, isto é, alguns com abordagem social, outros lidando com questões discutidas no campo social, embora nele não se inserissem, e aqueles que desenvolviam outras abordagens.

Todos os trabalhos que apresentavam abordagem social foram listados e encontram-se no anexo B. Já os trabalhos do segundo grupo aqueles que lidam com questões discutidas no campo social, juntamente com grupos populacionais não designados por recortes de saúde/reabilitação, e que ocorriam em equipamentos sociais ou da justiça ou ainda no território - tiveram 
sua análise demonstrada por se tratarem de experiências que apresentam pontos de convergência com trabalhos de natureza social, porém utilizando metodologias clínicas, ou do campo da saúde coletiva ou do campo do desenvolvimento global em seus aspectos cognitivos, emocionais, comportamentais, psíquicos ou físicos.

Julgou-se importante exemplificar essa categoria de trabalhos, dado que os desafios de sua classificação e análise encontram-se no que à primeira vista parecem detalhes, mas que na verdade revelam diferenças metodológicas fundamentais.

Portanto, trata-se de trabalhos destinados a grupos sociais como crianças e adolescentes em situação de abrigo, detentos do sistema prisional, adolescentes em conflito com a lei ou comunidades indígenas, que ocorriam no interior de equipamentos sociais ou da justiça ou mesmo no território. Porém, no que se referia ao enfoque metodológico das atuações descritas, este se encontrava voltado ao desenvolvimento global ${ }^{20,21}$, a avaliações clínicas ou comportamentais $^{22,23}$ ou a estratégias de saúde coletiva. ${ }^{24,25}$

Em alguns trabalhos voltados a grupos populacionais destinatários das políticas de assistência social, foram descritas atuações sobre os processos de exclusão/inclusão sociais e do acesso a direitos fundamentais, decorrentes do comprometimento de saúde apresentado pelo sujeito ou pela população. Tal quadro justificaria a intervenção do terapeuta ocupacional, identificado como profissional da saúde atuando sobre aspectos que resultam de uma condição de saúde ou de desenvolvimento desfavorável, temporária ou permanente. 
Esses trabalhos não foram selecionados, uma vez que a ação do terapeuta deu-se em função da preexistência de uma problemática de saúde que levou a um comprometimento do cotidiano e do grau de desvantagem ou exclusão social apresentado, ou seja, aqueles em que, na ausência de um quadro clínico de base, não haveria a necessidade da intervenção do profissional.

Um exemplo disso encontra-se no trabalho intitulado Estudo de caso: território como espaço terapêutico, uma abordagem em reabilitação. ${ }^{26}$ Trata-se do acompanhamento individual de uma adolescente que apresentava leucemia linfóide aguda. Os objetivos descritos eram:

1. conhecer a adolescente no espaço em que habita; 2 . estimulá-la para o retorno ao convívio social; 3 . realizar acompanhamento dos problemas funcionais advindos da hemiparesia; 4. dialogar permanentemente com os equipamentos sociais do território para apoiar sua rede de suporte. ${ }^{26}$

O acompanhamento foi realizado levando em conta tanto as necessidades de reabilitação da jovem quanto suas demandas em relação a uma maior participação e circulação social no que se refere, por exemplo, ao acesso à educação: "Busca-se a diminuição de suas desvantagens sociais, construindo possibilidades de retorno à escola e de inclusão social”. ${ }^{26}$

Porém, a atuação no âmbito escolar deu-se em função da problemática de saúde e não somente como uma questão de direito à 
educação, que qualquer jovem possui, tendo ou não alguma patologia ou deficiência. Esse é um ponto que diferencia uma abordagem clínica ou de saúde/reabilitação de uma abordagem social.

Nesta última, a problemática social enfrentada, bem como o alijamento dos direitos de cidadania, são focos do trabalho do profissional, enquanto o acesso a programas de saúde, de reabilitação e/ou tratamento são vistos como parte do complexo entremeio de necessidades e demandas que o sujeito não mais individual, e sim coletivo, apresenta. Portando, atua-se num movimento inverso, que vai do direito ao acesso à conquista do acesso, seja em relação à saúde, à educação, à cultura ou ao lazer, e não da saúde para a efetiva conquista de direitos, como o percurso assinalado no trabalho citado.

Saúde, educação, moradia, segurança, acesso à cultura e ao lazer fazem parte das garantias dos mínimos sociais, e por esse motivo são vistos como conseqüências do exercício da cidadania para toda e qualquer pessoa, independente de sua condição, por exemplo, de saúde.

É dessa maneira que se apresentam as abordagens de Terapia Ocupacional Social, as quais não se definem a partir das características da população, e sim do grau de distanciamento em que essa população se encontra do exercício de seus direitos fundamentais. ${ }^{\dagger}$

\section{A população-alvo da terapia ocupacional social é justamente aquela cujas maiores necessidades configuram-se com base em sua condição de excluída do}

\footnotetext{
$\dagger$ Conforme consta na Constituição de 1988 os direitos e garantias fundamentais englobam: direitos e deveres individuais e coletivos (art.5), direitos sociais (art. 6 a 11), direito à nacionalidade (art. 12 e 13), direitos políticos (art. 14 a 16) e os direitos dos partidos políticos (art. 17).
} 
acesso aos bens sociais e cuja problemática se manifesta pelo agravamento das condições de vida a que está submetida. Tal problemática pode ser identificada com a noção de pobreza ou também entendida como uma situação de vulnerabilidade, de 'apartação', na medida em que o acesso aos direitos de cidadania, mesmo que constitucionais, é diferenciadamente atribuído, traduzindose numa experiência de não cidadania, de não pertencimento. $^{27}$

Foram descritas em alguns trabalhos ações comunitárias e territoriais do terapeuta ocupacional, tanto em atendimentos fora dos equipamentos de saúde, quanto na mediação da relação da pessoa atendida com outros equipamentos de educação, culturais e de serviços, em que este profissional atua como facilitador do processo de inclusão social, do acesso a direitos e de exercício da cidadania.

Essas ações, se analisadas em separado, podem ser configuradas como de caráter social, já que buscam construção de redes de suporte e garantia de direitos. Porém, ao se verificar o contexto em que foram produzidas, fica claro que ocorreram como conseqüência do atendimento a uma pessoa que apresenta um quadro de doença ou deficiência de onde parte o encadeamento de ações técnicas e sem o qual tais ações não se processariam, ou seja, não haveria a necessidade da intervenção do terapeuta ocupacional. 
A situação de exclusão apresentada pela adolescente do trabalho anteriormente citado foi alvo da ação do terapeuta, porque é uma conseqüência da patologia apresentada. Em si e por si, ela não seria encarada como demanda pelo profissional de saúde, caso não houvesse a priori alguma disfunção ou patologia.

Foram igualmente encontrados trabalhos que, embora mencionassem uma abordagem voltada à questão da cidadania, na verdade não a mantinham como foco de sua ação, ${ }^{28}$ como ocorreu em Brinquedoteca: um espaço de exercício da cidadania infantil. ${ }^{29} \mathrm{O}$ texto discorre sobre o atendimento a crianças "[...] com alterações no desenvolvimento neuropsicomotor $[\ldots]^{29}$ que estavam em um abrigo municipal em função de abandono ou maus-tratos.

A autora considerava que a cidadania estava sendo trabalhada na medida em que se propiciava um ambiente acolhedor, acesso a lazer e a um brincar que possibilitasse às crianças um adequado desenvolvimento global. Ela assinala em seu parágrafo inicial:

Um dos direitos assegurados pelo Estatuto da Criança e do Adolescente é o direito à educação e ao lazer, visando ao pleno desenvolvimento de sua pessoa, preparando-a para o exercício da cidadania e qualificação para o trabalho. ${ }^{29}$ 
Porém, não faz qualquer referência a ações especificamente voltadas à condição de exclusão a que estavam submetidas, já que se tratava de crianças institucionalizadas por situações de vitimização.

O trabalho descreve também o modo como o brincar era utilizado como recurso para estabelecer um processo com finalidades terapêuticas, sem realizar qualquer discussão em relação às questões sociais enfrentadas pelas crianças (abandono, violência doméstica, pobreza). Da mesma forma, colocava questões relativas à deficiência como pontos principais a serem trabalhados, a fim de possibilitar a relação das crianças com o mundo:

A deficiência representa uma barreira entre a criança e os objetos que deve manipular, as pessoas, o mundo a descobrir e a imagem de si mesma que ela vai construir. O brincar pode minimizar essas barreiras prevenindo outras conseqüências, assim como contribuir para um processo reabilitador de natureza terapêutica. $^{29}$

Desse modo, demonstra a finalidade de sua abordagem, focada em propiciar estímulo e apoio ao desenvolvimento saudável das crianças em questão, como instrumento para que possam exercer sua cidadania. Ou seja, ambos, cidadania e desenvolvimento, não são trabalhados concomitantemente, e sim como sendo um anterior ao outro ou como a cidadania sendo uma conseqüência automática quando se proporcionam melhores condições de desenvolvimento pessoal. Portanto, o trabalho foi considerado como tendo uma identificação bastante explícita com práticas na área da reabilitação, e assim 
não pertencente ao campo social, apesar de ocorrer em um abrigo, equipamento da rede de assistência social.

Para efeito da presente análise, são consideradas abordagens de cunho social aquelas em que o exercício, o resgate, a construção de cidadania e o acesso a direitos são objetivos principais da atuação, e por isso devem ser alcançados mediante ações específicas e com finalidades definidas, e não como conseqüência de um trabalho realizado com outro enfoque, seja ele pedagógico ou terapêutico.

A afinidade temática, bem como o cerne do trabalho, enfatizando o desenvolvimento e a reabilitação, ficam ainda mais claramente definidos ao serem descritos seus resultados e conclusões:

[...] atualmente observa-se melhora na exploração e utilização do brinquedo de modo criativo e funcional além de diminuição de agressividade, e conseqüente melhora no relacionamento entre as crianças e destas com técnicos e acadêmicos; melhora no desenvolvimento psicomotor, concentração e socialização. ${ }^{29}$

Desse modo, mesmo que mencionado até no título, não houve, ao longo do trabalho, ou em sua conclusão, referência a ações específicas com vistas à problemática social da população em questão.

Alguns trabalhos surgiram a partir de temáticas da área da saúde, mas foram ampliando sua ação ao longo de seu desenvolvimento, para além das populações que apresentavam demandas relacionadas a essa área, 
chegando ao conjunto de pessoas do território em uma abordagem que progressivamente assumiu contornos comunitários e participação de outros atores sociais, que não somente os profissionais técnicos e a população diretamente atendida. ${ }^{30}$

Portanto, esses trabalhos foram considerados como tendo uma abordagem social, pois não selecionaram a população-alvo de suas ações segundo recorte de saúde, e sim de demandas sociais. Propuseram atuação articulada a outros grupos da comunidade, compartilharam o delineamento das ações com a própria população a que se destinavam, reconhecendo nela o papel de interlocutor e participante ativo na criação de estratégias para o equacionamento das demandas que apresenta.

Esse processo de transformação progressiva do olhar e das concepções de trabalho, de uma proposta de saúde para uma atuação já de caráter mais abrangente do ponto de vista do reconhecimento de necessidades e demandas da população em questão, pode ser visto no pôster Envelhecimento compartilhado: grupos comunitários - uma atuação possível em terapia ocupacional, ${ }^{31}$ no qual é descrito o percurso de um grupo de mulheres adultas e idosas, inicialmente atendidas em um Centro de Saúde Escola com quadros de "[...] depressão e outras alterações emocionais".31

Em seguida, após encerrado seu processo terapêutico, as integrantes do grupo solicitaram a continuidade dos encontros. Então, "[...] estimulou-se a organização de um grupo para encontros fora do espaço do Centro de Saúde, aberto para a participação de outras pessoas da comunidade", ${ }^{31}$ além de terem sido estabelecidos contatos com lideranças da comunidade católica da região, que cederam o espaço para os encontros. 
Desse modo, as ações e os objetivos do grupo extrapolaram ambiente e propósitos clínicos, indo ao encontro de demandas presentes no conjunto da população idosa da região, com a criação de um espaço que lhes proporcionasse participação social diferenciada.

Ficam explicitadas pelas autoras a nova dimensão e característica da abordagem que começam a desenvolver e que se distingue de uma abordagem clínica: "[...] percebemos que estamos construindo uma metodologia de trabalho para atuar em grupos comunitários, os quais possuem um caráter diferenciado dos grupos terapêuticos". ${ }^{31}$

\subsection{A Terapia Ocupacional Social em cada congresso}

Os seis CBTOs analisados ocorreram entre 1997 e 2007 e, apesar de assumirem características próprias no tocante à classificação dos temas enfocados, à compilação e à apresentação de resumos, no que se refere aos trabalhos de Terapia Ocupacional Social trouxeram muitas questões semelhantes e por vezes recorrentes. Algumas delas foram progressivamente sendo mais exploradas a cada evento, tornando possível perceber, por meio de uma análise longitudinal, a consolidação desse campo através de experiências profissionais e também de práticas vinculadas ao ensino em diversas regiões do país.

O percurso de crescimento do número de trabalhos apresentados em cada congresso e também do número de trabalhos de Terapia Ocupacional Social encontra-se descrito na Tabela 1. Nela é possível notar a predominância de autores do estado de São Paulo na apresentação de trabalhos de Terapia Ocupacional Social, como também a existência de uma correlação da produção 
nessa área com o ensino, tendo em vista a relação de muitos autores com instituições de ensino superior (IES).

Tabela 1 - Distribuição dos trabalhos de Terapia Ocupacional apresentados em CBTO segundo data do congresso, número, natureza temática, procedência e vínculo de autores à instituições de ensino superior

\begin{tabular}{|c|c|c|c|c|c|}
\hline \multirow[b]{2}{*}{$\begin{array}{c}\text { CBTO }^{1} \\
\text { Data }\end{array}$} & \multirow[b]{2}{*}{$\begin{array}{l}\text { Número Total } \\
\text { de Trabalhos } \\
\text { Apresentados }\end{array}$} & \multicolumn{4}{|c|}{$\begin{array}{l}\text { TRABALHOS DE TERAPIA OCUPACIONAL } \\
\text { SOCIAL }\end{array}$} \\
\hline & & Número & $\begin{array}{c}\text { Trabalhos do } \\
\text { Estado de } \\
\text { São Paulo }\end{array}$ & $\begin{array}{l}\text { Trabalhos de } \\
\text { Outros } \\
\text { Estados ou } \\
\text { Países }\end{array}$ & $\begin{array}{c}\text { Trabalhos } \\
\text { de } \\
\text { Autores } \\
\text { Ligados à } \\
\text { IES }^{2}\end{array}$ \\
\hline 1997 & 32 & 1 & 1 & 0 & 1 \\
\hline 1999 & 260 & 13 & 12 & 1 & 11 \\
\hline 2001 & 421 & 23 & 20 & 3 & 17 \\
\hline 2003 & 247 & 14 & 9 & 5 & 9 \\
\hline 2005 & 439 & 21 & 17 & 4 & 19 \\
\hline 2007 & 472 & 33 & 29 & 4 & 30 \\
\hline TOTAL & 1871 & 105 & 88 & 17 & 87 \\
\hline
\end{tabular}

FONTE: Anais dos Congressos Brasileiros de Terapia Ocupacional dos anos 1997, 1999, 2001, 2003, 2005, 2007

${ }^{1}$ Congresso Brasileiro de Terapia Ocupacional

2 Instituições de Ensino Superior

Após ter sido verificado, com o auxílio da Tabela 1, o panorama em termos numéricos da Terapia Ocupacional Social ao longo dos congressos analisados, serão descritos a seguir os temas e as questões que foram sendo abordados por esses trabalhos a cada evento e também alguns aspectos numéricos que necessitam aprofundamento e melhor visualização.

No V CBTO, que ocorreu em Belo Horizonte, Minas Gerais, em 1997, com o tema "Horizontes da Clínica à Pesquisa", foram apresentados 32 trabalhos, dentre os quais apenas um com temática social, de autoria de Sandra Maria Galheigo. Trata-se de uma reflexão crítica acerca dos programas tradicionais de profissionalização destinados a adolescentes provenientes de famílias de baixa renda e que, segundo análise da autora, se fundamentavam 
em práticas assistencialistas e/ou disciplinares. O trabalho visa também à conscientização dos terapeutas ocupacionais a respeito dos reais conteúdos discriminatórios e de culpabilização da população-alvo (adolescentes) pela problemática social enfrentada, conteúdos assinalados como sendo subjacentes à implementação de diversas propostas e programas de profissionalização. $^{32}$

O congresso seguinte, realizado em São Paulo em 1999, teve o tema "Trajetórias e Perspectivas da Terapia Ocupacional". Nesse evento houve um aumento do número de trabalhos que se referiam à Terapia Ocupacional Social, sob a forma de relatos de experiências, além de reflexões sobre o surgimento e o desenvolvimento desse campo na terapia ocupacional.

Os trabalhos referentes ao campo social formaram um conjunto de 13 exposições, entre comunicações orais e pôsteres, em sua maioria expondo experiências e/ou reflexões sobre a área, desenvolvidas de maneira articulada a iniciativas de pesquisa e extensão de instituições de ensino superior, quase todas sediadas no estado de São Paulo. Eram elas: Pontifícia Universidade Católica de Campinas (PUCCamp), Universidade de São Paulo (USP), Universidade Federal de São Carlos (UFSCar) e Universidade Federal de Minas Gerais (UFMG).

Nesse congresso, a Terapia Ocupacional Social ganhou um contorno mais definido não somente em função de uma presença um pouco maior de trabalhos em relação ao último congresso, como também no que se refere à classificação que recebeu por parte do evento, pois os trabalhos foram organizados pelo congresso sob os títulos: "A terapia ocupacional contribuindo para o resgate do ser social e da cidadania", e também "Abordagens de terapia 
ocupacional com grupos em situação de risco pessoal e social". ${ }^{33}$ Tais denominações já demonstravam o que se configuraria como um norteador para a caracterização do campo: a proposta de atuação fora do eixo estruturador saúde-doença e com uma população não caracterizada segundo enfoques exclusivamente de saúde, mas sim sociais.

Foram igualmente apresentados os primeiros escritos em que o social foi visto não mais como um aspecto a ser considerado pelos terapeutas ocupacionais em sua prática, mas como alvo da atuação desses profissionais, ampliando, assim, o foco de sua atuação para além do indivíduo e as problemáticas que seu corpo ou mente encerram, ou ainda as conseqüências relacionais e de inclusão/exclusão sociais que delas decorrem.

Foram colocadas questões relativas não apenas à ampliação do foco de trabalho do terapeuta para a problemática social da população que atende, mas também a uma nova visão de sujeito, contextualizado em seu meio social, na cultura e comunidade, e como representante de demandas remetidas não só a ele, mas principalmente ao grupo social que representa.

Outro assunto abordado foi o surgimento do "social" como campo na terapia ocupacional e sua contextualização no período histórico e político em que ocorreu: ao final dos anos 1970 no Brasil. Esses foram alguns dos temas discutidos naquele momento e que serviriam mais tarde como base para outros trabalhos apresentados em congressos subseqüentes.

Até esse congresso, a produção relacionada ao campo social esteve predominantemente representada por autores oriundos do estado de São Paulo ${ }^{\ddagger}$ e vinculados direta ou indiretamente a IES (tendência que se

\footnotetext{
‡ A produção que esteve presente nos CBTOs de um modo geral parece, em certa medida, influenciada por autores do estado de São Paulo, já que trabalhos oriundos desse estado sempre se fizeram
} 
manteve nos congressos restantes como ilustra o Gráfico 1). Isso parece apontar para o surgimento do processo de divulgação de novas práticas e reflexões relacionadas a esse campo, realizado por profissionais paulistas, influenciando ou motivando trabalhos que surgiriam nos congressos seguintes, em que se amplia a participação de autores de outros estados e até internacionais.

Gráfico 1 - Trabalhos de Terapia Ocupacional social segundo a procedência de seus autores

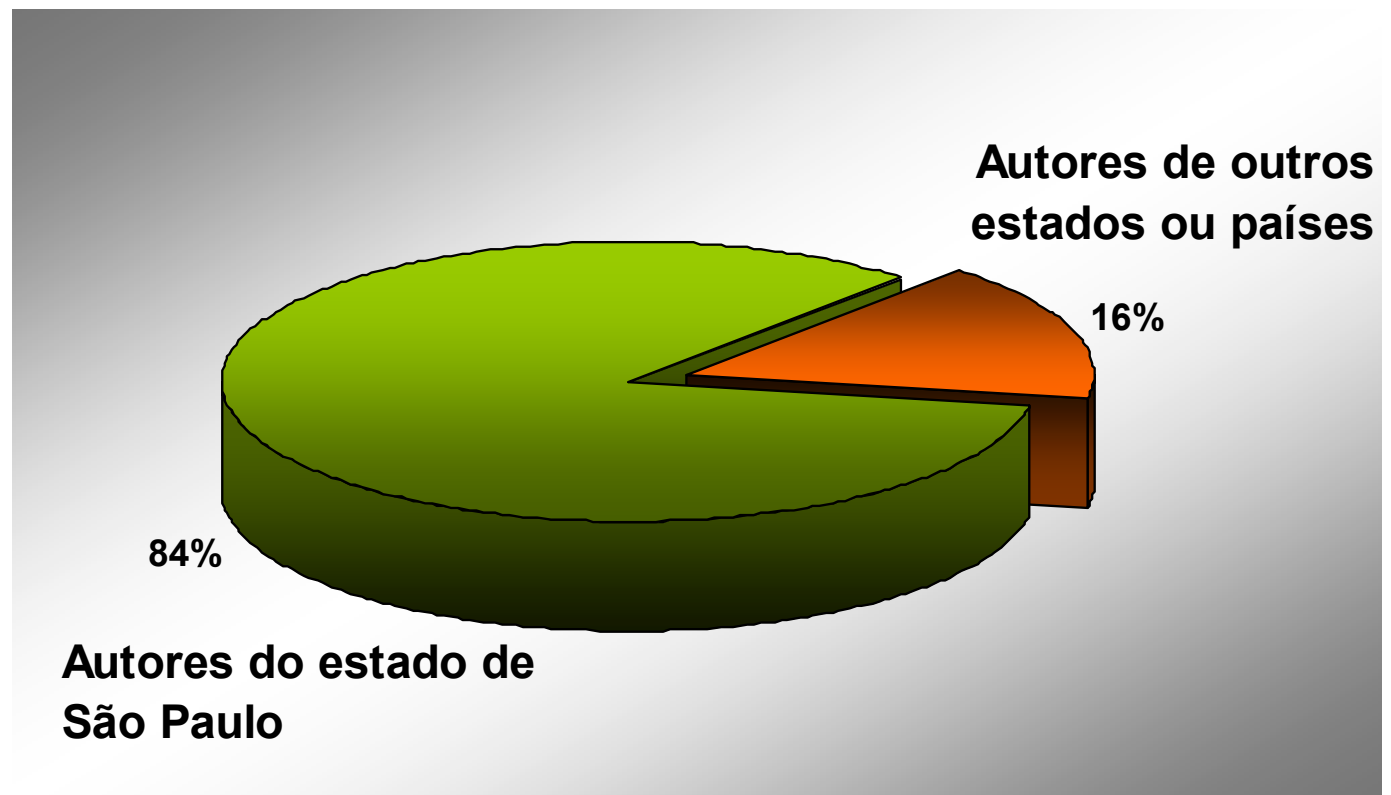

FONTE: Anais dos Congressos Brasileiros de Terapia Ocupacional dos anos 1997, 1999, 2001, 2003, 2005, 2007

No VII CBTO, realizado em Porto Alegre, Rio Grande do Sul (2001), o crescimento do número de trabalhos apresentados confirma-se como uma tendência, assim como o número de trabalhos com temática social (Tabela 1). Ao comparar esses dois valores, ao longo dos seis congressos pesquisados, é possível notar que ambos desenvolveram um comportamento

presentes de maneira significativa em diversos eventos como aponta Falcão ${ }^{34}$ em pesquisa envolvendo os CBTOs desde sua primeira edição em 1989 até o de 2001. A autora ressalta que: "a representação profissional evidencia, em quase todos os congressos, um predomínio de profissionais da região e/ou estado sede do evento, havendo ainda presença quantitativamente importante de profissionais do estado de São Paulo". 
semelhante, apresentando certo paralelismo nos momentos de crescimento e diminuição e com ligeira diferença no congresso de 2005, conforme demonstrado nos Gráficos 2 e 3 abaixo.

Gráfico 2 - Curva de crescimento do número total de trabalhos apresentados nos Congressos Brasileiros de Terapia Ocupacional

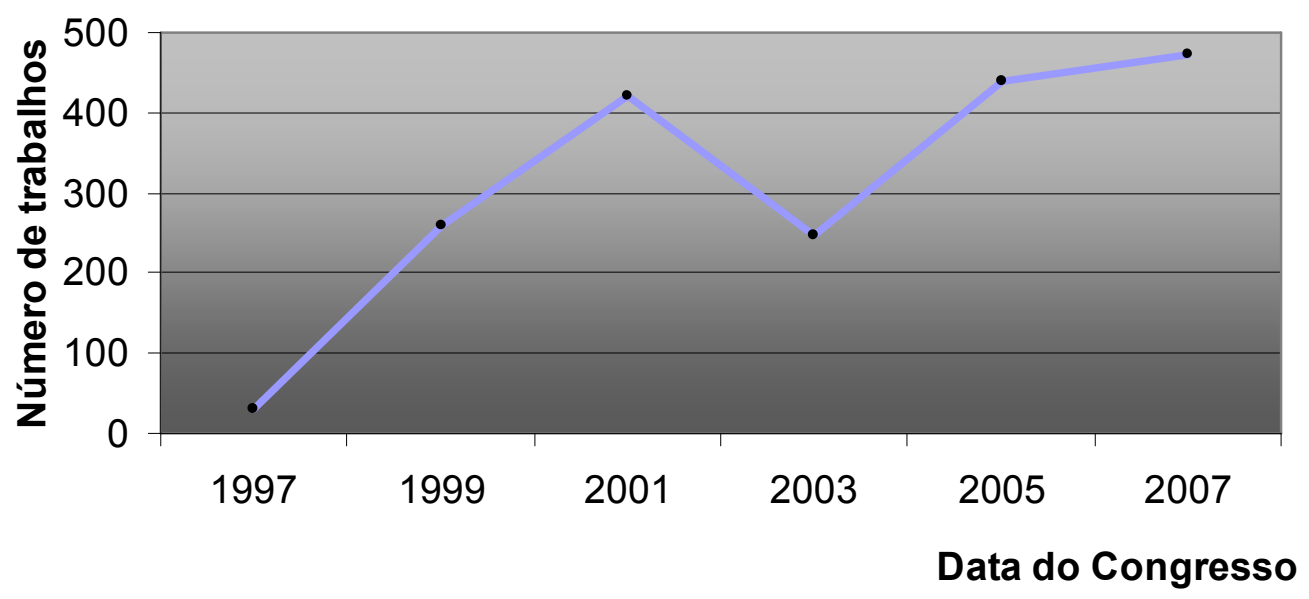

FONTE: Anais dos Congressos Brasileiros de Terapia Ocupacional dos anos 1997, 1999, 2001, 2003, 2005, 2007

Gráfico 3- Curva de crescimento do número de trabalhos de terapia ocupacional social apresentados nos Congressos Brasileiros de Terapia Ocupacional

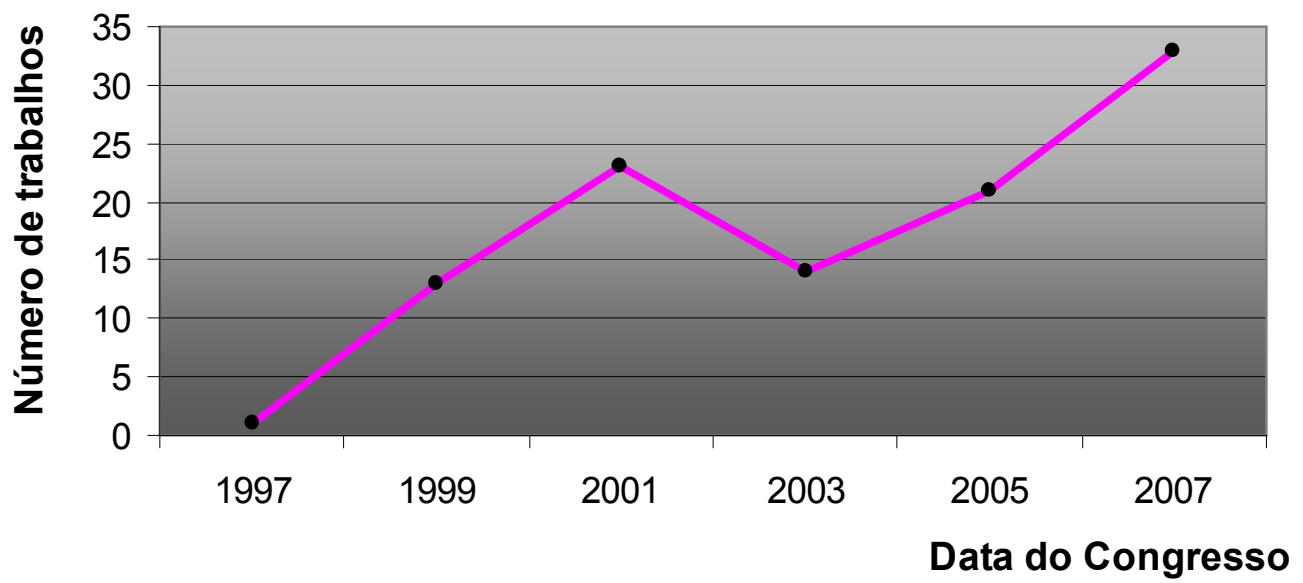


FONTE: Anais dos Congressos Brasileiros de Terapia Ocupacional anos 1997, 1999, 2001, 2003, 2005, 2007

No congresso de Porto Alegre houve ao todo 421 trabalhos apresentados, dos quais 23 foram classificados como tendo abordagem de caráter social. Eles se dividiram entre relatos de experiências de intervenção junto a populações em situação de risco pessoal e social, divulgação de projetos desenvolvidos a partir de parceria entre universidades e movimento social urbano, apresentações de iniciativas de geração de trabalho e renda, pesquisas, análises críticas sobre programas sociais governamentais e sobre o papel político do técnico.

Ao contrário do que ocorreu no congresso anterior, em que foram muito abordadas questões sobre a constituição do campo social, bem como os pressupostos teóricos a ele relacionados, nesse evento os trabalhos de Terapia Ocupacional Social estiveram mais voltados para a apresentação de experiências e projetos de intervenção.

Um tema bastante enfocado foi o desemprego, enquanto problemática a ser considerada pelo terapeuta ocupacional. Os trabalhos que se debruçaram sobre o assunto descreviam a diminuta participação social e o agravamento de processos de exclusão causados pelo desemprego e mostravam alternativas surgidas da economia solidária e da organização de grupos de auto-gestão.

Os objetivos descritos por eles podem ser sintetizados em:

Apresentar os princípios da Economia Solidária e articulálos às atuais tendências e experiências, onde a terapia 
ocupacional amplia sua ação para além dos serviços de saúde e assume compromissos com a inclusão social de populações marginalizadas, atuando em parceria com a comunidade. $^{35}$

Outra característica levantada/observada foi o fato de que 17 dos 23 trabalhos selecionados eram de autores vinculados a IES (Tabela 1) e se referiam a programas de extensão universitária, formação profissional ou pesquisa, enquanto o restante desses autores possuía vínculos com projetos sociais, cooperativas de trabalho ou órgãos do governo na área da assistência e desenvolvimento social.

A dimensão política do trabalho do terapeuta nesse campo - além da preocupação com necessidades e demandas "reais", contextualizadas no território da população - e o desatrelamento de abordagens essencialmente clínicas e/ou realizadas no interior de equipamentos da saúde foram questões retomadas nesse congresso.

O VIII CBTO, realizado em Foz do Iguaçu, Paraná (2003), apresentou perfil bastante atípico em relação ao movimento de progressiva estruturação e crescimento assumido em cada evento, pois registrou um número de trabalhos consideravelmente inferior ao do congresso anterior (Gráfico 1) e também não realizou qualquer classificação do ponto de vista temático ou de conteúdo dos trabalhos apresentados, de modo que houve apenas subdivisão destes segundo formato de apresentação em painéis ou pôsteres. 
Dentre os assuntos abordados pelos trabalhos de Terapia

Ocupacional Social estão: a atuação junto a grupos populacionais em situação de risco ou vulnerabilidade social, na perspectiva da efetivação de políticas setoriais a eles relacionadas e no apoio à construção de projetos de vida e alternativas de enfrentamento das diferentes faces da exclusão vivenciadas pelas populações descritas. São elas: crianças trabalhadoras em centros urbanos, mulheres ou adolescentes em situação de rua, adolescentes autores de atos infracionais, pessoas vivendo desemprego estrutural, crianças abrigadas.

Foram também apresentadas diferentes modalidades de atuação territorial seja comunitária, seja em espaços públicos, além de experiências de apoio à organização de grupos comunitários. Como nos demais congressos analisados, é notória a presença de muitos trabalhos referentes a pesquisas relacionadas ao ensino e a experiências de extensão universitária.

O IX CBTO realizou-se no ano de 2005, em Recife, Pernambuco. Nesse evento foram retomadas questões metodológicas e de formulação teórica da Terapia Ocupacional Social e, pela primeira vez em um congresso brasileiro, houve um curso específico voltado a essa temática, ministrado pelas principais autoras de referência para a área, Sandra Galheigo, Denise Barros e Roseli Lopes.

Surgem nesse congresso, pela primeira vez, questões e temáticas envolvendo populações definidas por traços culturais e étnicos diferenciados, como o caso de índios e negros. A abordagem descrita deu-se tendo como perspectiva o estabelecimento de diálogos interculturais. 
No X CBTO, ocorrido em 2007, em Goiânia, Goiás, poucos dos trabalhos selecionados identificam-se explicitamente como sendo de terapia ocupacional social. A maioria deles descreve suas ações, pesquisas e objetivos, sem mencionar filiação a campo de conhecimento específico. Uma pequena parcela dos trabalhos selecionados apresenta-se exercendo "práticas terapêuticas". Porém, na descrição de seus objetivos, abordagens e ações, volta-se para o acesso aos direitos da população a que se referem, ou possui como foco demandas levantadas em virtude da vulnerabilidade social a que está submetido determinado grupo populacional, ou, ainda, empenham-se esforços na elaboração de estratégias e alternativas para o estabelecimento ou ampliação de suportes sociais mais sólidos.

Esses últimos trabalhos suscitam questionamentos acerca da clareza de seus autores sobre a natureza das abordagens que propõem quanto à filiação de campo epistemológico dentro da Terapia Ocupacional. Cabe indagar as razões de tais opções. Há um desconhecimento do que já vem sendo produzido em terapia ocupacional nesse campo? Ou seria uma opção por uma não filiação ou especialização?

É possível concluir, contudo, que as práticas de Terapia Ocupacional no campo social vêm se diversificando e multiplicando pelo Brasil e extrapolando, mesmo que ainda timidamente, o eixo de produção de conhecimento que tradicionalmente prepondera no sudeste do país.

Esse crescimento pode parecer pouco expressivo quando comparado a outras áreas, porém tem se verificado de maneira concreta que o tema vem ocupando cada vez mais espaços nos congressos da categoria,

\footnotetext{
$\S$ Um exemplo disso pode se encontrado no pôster: "Experiências de terapia ocupacional no processo de ressocialização de detentos". ${ }^{36}$
} 
mediante apresentação não só de trabalhos, como também de minicursos, além da organização de eventos próprios como o que ocorreu no X CBTO: I Simpósio de Terapia Ocupacional no Campo do Social - alternativas da Terapia Ocupacional no Campo do Social. Tudo issodemonstrou o amadurecimento e o acúmulo que as práticas e discussões nesse campo vem alcançando no Brasil.

No que se refere ao conteúdo, os trabalhos trouxeram alguns temas até então não explorados em congressos anteriores, tais como: atuação profissional no campo social, a partir de um relato auto-biográfico, ${ }^{37}$ reflexões sobre a terapia ocupacional social e suas conexões com o campo filosófico da complexidade ${ }^{38}$ desafios que os terapeutas ocupacionais enfrentam em sua relação com as organizações não-governamentais e o terceiro setor, ${ }^{39}$ análise da concepção de ocupação existente em um movimento social rural e sua relação com a constituição da identidade social ${ }^{40}$ e, por último, uma síntese das questões que vêm permeando o desenvolvimento do campo social na Terapia Ocupacional, incluindo as dificuldades da inserção profissional e a pouca comunicação que se estabelece entre autores que produzem conhecimento nessa área em diversos países.

Outra diferença em relação aos congressos anteriores consiste no fato de que alguns dos trabalhos de terapia ocupacional social expostos tiveram co-autoria de profissionais de outras categorias, provenientes da arteeducação, da educação superior e da saúde coletiva. Esses trabalhos apresentaram como ponto em comum a população-alvo composta por crianças e jovens em situação de vulnerabilidade social, porém cada um deles em um 
aspecto diverso relacionado a políticas públicas, estratégias de intervenção ou propostas de atuação.

Quanto às influências teóricas, os trabalhos de Terapia Ocupacional Social nesse congresso em sua maioria partem de fontes bibliográficas e teóricas semelhantes, porém há os que não utilizam a bibliografia ou os autores considerados de referência para o campo. É interessante observar que estes últimos apresentam expressivos pontos de convergência e identificação com os demais, o que demonstra que, mesmo tendo bibliografia diferenciada e tratando-se de experiências realizadas em diferentes regiões do país, há certa compatibilidade entre abordagens, temáticas e populações, sem a presença de discrepâncias marcantes.

Isso parece indicar que o crescimento da Terapia Ocupacional no campo social vem se dando com uma coerência compartilhada e que retroalimenta seu delineamento enquanto campo de atuação e saberes próprios dentro da Terapia Ocupacional.

O crescimento numérico de trabalhos com essa temática é bastante expressivo e também apresenta comportamento semelhante ao da Terapia Ocupacional como um todo, conforme anteriormente mencionado, ou seja, com paralelismo entre momentos de aumento e diminuição (vide Gráficos 2 e 3). Porém, observou-se que o índice de crescimento da área, considerando-se do primeiro ao último CBTO analisado, foi de $3.200 \%$, mais que o dobro do índice de crescimento dos trabalhos de terapia ocupacional como um todo, que foi de $1.375 \%$. No gráfico abaixo é possível comparar esses dois índices evento a evento.

\footnotetext{
** A despeito do notável crescimento da representação da área nos CBTOs, os altos valores também se devem ao fato de tratar-se de um campo que faz parte de um universo profissional ainda pequeno,
} 
Gráfico 4 - Comparação entre os índices de crescimento de trabalhos de Terapia Ocupacional Social e do total de trabalhos apresentados em cada Congresso Brasileiro de Terapia Ocupacional

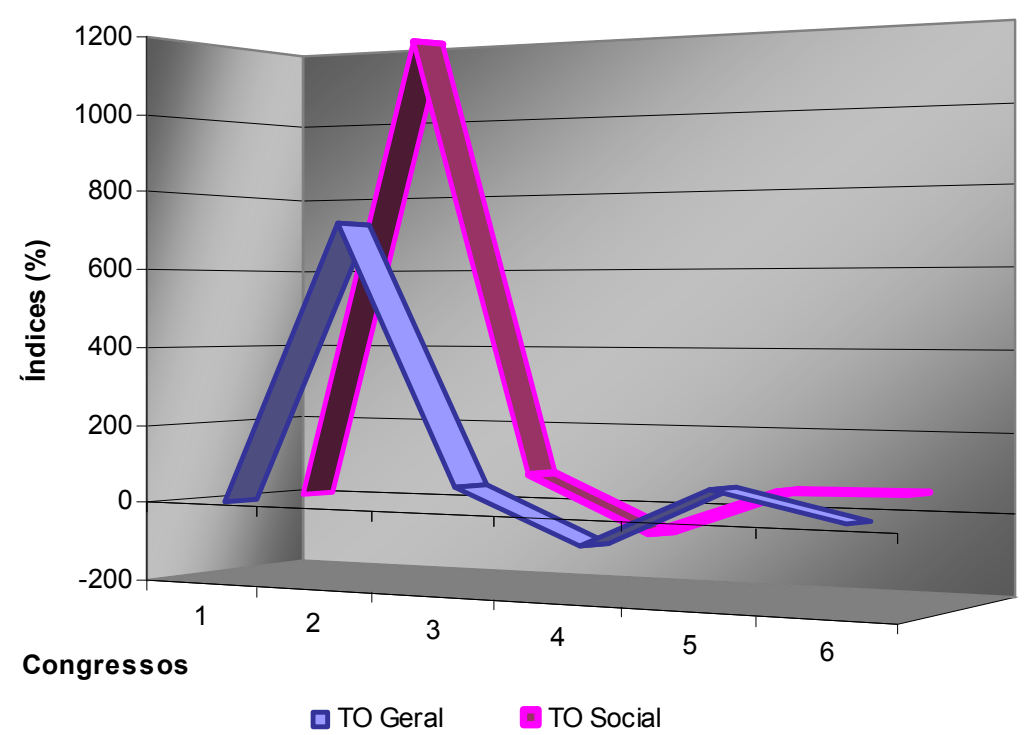

FONTE: Anais dos Congressos Brasileiros de Terapia Ocupacional dos anos 1997, 1999, 2001, 2003, 2005, 2007

Examinando os seis CBTOs citados, foi possível perceber o crescimento do número de trabalhos de Terapia Ocupacional Social e o modo como esse campo vem sendo explorado pelos terapeutas ocupacionais, seja por meio de experiências em que buscam desenvolver ações para efetivação de direitos previstos na legislação brasileira e nas políticas públicas, e também como esses profissionais expressam um olhar crítico em relação a programas e projetos sociais voltados a populações marginalizadas e em situação de vulnerabilidade social, além do papel político-ideológico de sua ação técnica.

Outro ponto relevante na produção relacionada ao campo social foi a predominância de autores do estado de São Paulo (que se verificou ao 
longo de todos os congressos pesquisados), responsáveis por $84 \%$ dos trabalhos relacionados ao campo social.

Foi também evidente a importante influência de reflexões oriundas de profissionais ligados a instituições de ensino sobre o panorama de constituição do campo social na Terapia Ocupacional, já que representaram $83 \%$ dos trabalhos publicados. Contudo, fica a dúvida sobre o número de profissionais atuando nesse campo e que não publicaram trabalhos nos congressos pesquisados. Para tal levantamento seria necessária uma investigação de outra ordem.

Essa expressiva participação de autores ligados às IES na produção relacionada ao campo social sugere que sua estruturação, como campo de atuação e pesquisa para os terapeutas ocupacionais, tem recebido influência do meio acadêmico e com ele vem estabelecendo diálogo contínuo.

Desse modo, a expansão que o campo social vem alcançando na Terapia Ocupacional brasileira, nos últimos anos, parece estar intimamente relacionada a iniciativas de ensino, pesquisa e, sobretudo, extensão de programas universitários atentos à precarização das condições de vida e do acesso aos direitos fundamentais a que vem sendo historicamente submetida grande parte da população no Brasil.

Soma-se a isso a recente regulamentação do Sistema Único da Assistência Social (SUAS), trazendo algumas contribuições conceituais importantes para a delimitação das especificidades desse campo, tendo em vista os destinatários das políticas de seguridade social, a necessidade de garantia dos mínimos sociais, bem como seu caráter integrador com políticas de outras áreas. 
É igualmente relevante a presença de terapeutas ocupacionais trabalhando em programas criados pela Política de Assistência Social, tanto em órgãos governamentais como em não-governamentais. Esses programas foram alvo de diversos trabalhos em que se analisam os propósitos desses programas, sua efetividade e alcance, bem como as contribuições da Terapia Ocupacional naquele contexto.

Desse modo, a diversificação de trabalhos apresentados reflete a crescente atuação do terapeuta ocupacional nos espaços sociais, seja na assistência direta, seja participando de fóruns de discussão e conselhos de diretos, na formação de redes ou na proposição de políticas.

A ampliação da atuação desses profissionais no campo social também vem se dando em função do aumento de organizações não governamentais no cenário social brasileiro e de forma paralela à crescente profissionalização do terceiro setor.

Convém salientar que a inserção do terapeuta ocupacional no terceiro setor vem encontrando uma série de desafios perante as contradições vivenciadas atualmente pelas organizações não-governamentais brasileiras, como ressaltam Lopes, Malfitano e Borba. ${ }^{39}$ Porém, a despeito de sua incorporação ao campo, posterior a outras categorias profissionais, como coloca Galheigo, citado em Barros, Lopes e Galheigo, ${ }^{12}$ a crescente produção nos CBTOs parece refletir o esforço de sistematização das reflexões e vivências desses profissionais, bem como as experiências e contribuições que vêm sendo engendradas em meio às imensas contradições presentes no bojo do emaranhado sociopolítico e assistencial do país. 
A Terapia Ocupacional Social está se estruturando, assim como o próprio campo social assistencial, em um Brasil com uma história recente de regime totalitário e em que as políticas de transferência de renda são, no contexto atual, amplamente propagandeadas pelo governo como principal alternativa no combate às desigualdades sociais e à pobreza, todavia sem impactos de natureza estrutural. ${ }^{41}$

Por fim, analisar os trabalhos publicados nos CBTOs permitiu conhecer uma gama de projetos e programas sociais em que estão inseridos terapeutas ocupacionais, distribuídos por várias regiões do país, o desdobramento de reflexões oriundas do ensino em práticas que buscam a transformação social, o engajamento do técnico como agente desse processo e o modo como o terapeuta ocupacional vem se integrando ao campo como trabalhador social, e não como trabalhador de saúde no campo social (o que retrata a mudança de foco do trabalho do terapeuta, que até então se centrava no sujeito, dirigindo-se para a questão social vivenciada por esse sujeito e pelo grupo social a que pertence). Essa diferenciação nas atuações dos terapeutas ocupacionais tornou-se progressivamente clara e, com ela, a terapia ocupacional pôde conquistar mais uma possibilidade de intervenção e de crescimento. 


\section{A constituição do campo da Terapia Ocupacional Social e seus autores}

Segundo Bourdieu, ${ }^{8}$ para que se possa compreender ou analisar campos como o intelectual ou o político é preciso perceber as posições ocupadas pelos agentes desses campos e de que forma essas posições se articulam. Desse modo, é impossível estudar o desenvolvimento de um determinado campo científico sem abordar os agentes (autores) que o compõe.

Tal passo é necessário para que se possa indagar não como tal escritor chegou a ser o que é, mas o que as diferentes categorias de artistas e escritores de uma determinada época e sociedade deviam ser do ponto de vista do habitus socialmente constituído, para que Ihes tivesse sido possível ocupar as posições que lhes eram oferecidas por um determinado estado do campo intelectual e, ao mesmo tempo, adotar as tomadas de posição estéticas ou ideológicas objetivamente vinculadas a essas posições. ${ }^{42}$

Sendo assim, não nos cabe proceder a uma análise do percurso individual de cada um dos autores que escrevem sobre o campo social da terapia ocupacional, e sim descrever quem são os autores/pesquisadores que abordam a constituição do mesmo - ou, como coloca Bourdieu, os agentes 
desse campo -, quais suas principais contribuições e que posições ocupam nesse espaço.

Os Congressos Brasileiros foram a fonte primeira através da qual se obteve um panorama de profissionais/autores do campo da Terapia Ocupacional Social e, entre eles, os que vêm abordando as bases conceituais e constitutivas desse campo no Brasil.

Paralelamente ao levantamento realizado nos CBTOs, pesquisouse a produção científica publicada nos principais periódicos de Terapia Ocupacional do estado de São Paulo, a saber: a Revista de Terapia Ocupacional da Universidade de São Paulo e os Cadernos de Terapia Ocupacional da Universidade Federal de São Carlos, como também na base de dados SCIELO e em coletâneas, livros e dissertações.

Essas fontes, em conjunto com os trabalhos dos CBTOs, revelaram grande parte da produção bibliográfica da Terapia ocupacional Social nos últimos 18 anos. $^{\dagger \dagger}$ Sabe-se que existem, ainda, trabalhos publicados em outros congressos e simpósios, mas no presente estudo optou-se por utilizar somente as fontes já citadas.

O levantamento bibliográfico demonstrou também a existência de grupos que ao longo desse período vêm se dedicando especificamente ao desenvolvimento de metodologias de intervenção e pesquisa social.

Os primeiros autores a produzir escritos sobre o que viriam a ser os conhecimentos fundantes da Terapia Ocupacional Social possuíam experiências comuns com relação ao trabalho em instituições totais e disciplinadoras, a afinidade com o ideário de desinstitucionalização recém-

\footnotetext{
${ }^{\dagger}$ Esse período refere-se até setembro de 2008, momento em que se encerrou a coleta de dados para esta pesquisa.
} 
trazido ao Brasil, a noção que se formava naquele momento da necessidade de se perceber as implicações políticas e ideológicas da ação técnica e a quais objetivos essa ação se voltava (adaptação social ou construção de autonomia).

Eram tempos de ressurgimento do estado democrático e de seus marcos legais como a Constituição de 1988 e também de diversos movimentos sociais. Esses autores, cada qual a seu modo, participaram da luta por direitos das populações que atendiam e da organização das primeiras políticas setoriais para segmentos tidos como mais frágeis da sociedade, como o caso das crianças, dos idosos e das pessoas com deficiência. Pode-se dizer que havia uma inquietação com a situação de exclusão e marginalização social de populações que não necessariamente apresentavam problemáticas relacionadas à saúde. Galheigo ${ }^{43}$ afirma que:

A terapia ocupacional social surgiu, portanto, em meados dos anos setenta sob a égide de um regime autoritário que impunha um sistema disciplinador e segregador embora mistificado pelo tecnicismo, que ao conceder poder aos técnicos, garantia a conformidade à violência da desigualdade e da conformação social. A crítica a tal modelo, entretanto, estaria sendo gestada, na medida em que neste mesmo período o cenário político do país começava a se modificar, a sociedade civil começava a se reorganizar e a questionar as políticas existentes, e a retomada do debate acadêmico possibilitava a 
recolocação da questão da marginalidade social sob a perspectiva do conflito social. ${ }^{44}$

Outro ponto de aproximação entre suas trajetórias de trabalho consiste em sua vinculação a universidades como docentes ou auxiliares de ensino, posições que foram sendo ocupadas à medida que acontecia a expansão dos cursos de graduação de Terapia Ocupacional no país. Estes acompanharam a ampliação do ensino superior no Brasil experimentada nas décadas de 80 e 90 do século $X X$, sobretudo no ramo privado. ${ }^{\ddagger}$

Nos anos 1990, a Terapia Ocupacional já havia passado pela fase em que possuía uma visão compartimentalizada do sujeito e também pelo esforço de caracterização das diferentes tendências de atuação profissional através de correntes metodológicas e experimentava iniciativas de trabalho em áreas diferentes das já estabelecidas saúde mental, disfunções físicas e reabilitação ${ }^{\S \S}$. Conforme apontado por Galheigo. ${ }^{45}$

É a partir dos anos 90 que as práticas no campo da terapia ocupacional social se ampliam para ir ao encontro da demanda por programas sociais variados, a partir da reestruturação das políticas setoriais, dentre as quais a

\footnotetext{
㧊 É importante notar que a maioria dos autores que escrevem sobre o campo da Terapia Ocupacional social no estado de São Paulo pertence aos quadros funcionais de universidades públicas onde coordenam projetos de intervenção e pesquisa nesse campo. Essa realidade vem causando impacto na produção científica no campo o que pode ser verificado, por exemplo, ao se constatar que aproximadamente $45 \%$ dos trabalhos de terapia ocupacional social encontrados nos últimos seis congressos brasileiros provêm de autores e pesquisadores de universidades da rede pública de ensino do estado de São Paulo.

§ Histórico da constituição do campo da terapia ocupacional social no Brasil pode ser encontrado em Galheigo (2005) ${ }^{45}$ e também em Galheigo (1997). ${ }^{32}$
} 
Lei Orgânica da Saúde, a Lei Orgânica da Assistência Social e o Estatuto da Criança e do Adolescente. ${ }^{46}$

No começo dos anos 1990, têm início as primeiras publicações e reflexões sobre a constituição de um campo específico de intervenção social na Terapia Ocupacional e as contradições que poderiam advir disso:

[...] ao delimitarmos um campo de intervenção como social, [...] adentramos um território antes inexistente, isto é, agrupamos uma nova parcela da população segundo novos grupos de patologias, as patologias sociais. Assistimos a um alargamento da noção de anormalidade, de doença, etc... Quem são esses indivíduos, novos objetos de estudo e de intervenção por parte dos terapeutas ocupacionais e de outros técnicos de saúde? Como se constituem? Quem os define $?^{47}$

Essas são algumas das questões que foram paulatinamente exploradas à medida que a Terapia Ocupacional Social se delineava como campo de atuação e pesquisa ao longo da década de 1990. Ao final desse período, inicia-se a discussão da cidadania e do exercício dos recémconquistados direitos fundamentais por parte de diversos grupos populacionais atendidos pela terapia ocupacional ${ }^{48}$ e do necessário reposicionamento profissional para lidar com a assim chamada exclusão social: 
O papel de adaptador dá enfim lugar ao de articulador social. Esta nova função vem do entendimento de que os excluídos necessitam conhecer seus pares e, juntos, entender os motivos de sua exclusão. [...] Esse novo papel de tecelão social, a ser desenvolvido pelos trabalhadores sociais e da saúde, implica na elaboração de novas abordagens e estratégias. ${ }^{49}$

Todavia, no final da década de 1990, terapeutas ocupacionais docentes de três universidades paulistas (USP-SP, UFSCar e PUCCamp) constituíram um grupo voltado ao desenvolvimento de ações e pesquisas no campo social. Esse grupo passou a conduzir conjuntamente as reflexões sobre a atuação técnica nesse campo e suas implicações teórico-metodológicas para a Terapia Ocupacional que já haviam sido iniciadas de forma paralela em cada uma dessas instituições.

O Projeto Metuia ${ }^{50}$, como ficou conhecido, passou a publicar os resultados de suas ações e pesquisas utilizando, para construir sua definição de população alvo das intervenções no campo social, os conceitos de desfiliação e de ruptura de redes sociais de suporte cunhados pelo sociólogo Robert Castel $^{51-53}(1994,1997$ e 2005).

Com o VI CBTO em 1999, houve a divulgação de experiências de diversos autores, em sua maioria ligados ao Projeto Metuia, em que eram descritas intervenções abordando as problemáticas sociais enfrentadas por crianças e adolescentes (em conflito com a lei, em situação de rua, em abrigos) e no interior de movimentos de luta por moradia. Também nesse ano foram 
publicadas discussões sobre pressupostos específicos da atuação no campo social como sua definição "fora do eixo estruturador saúde-doença", ${ }^{54}$ bem como a elaboração da trajetória do social na Terapia Ocupacional em seus diálogos com as políticas públicas e também no ensino de graduação. ${ }^{43}$

Nos anos 2000, esses debates tornaram-se mais complexos, e a produção de grupos de pesquisa do campo social, assim como de autores e profissionais independentes, cresceu e se diversificou, passando a ocupar espaços em todos os congressos brasileiros da categoria. Essas discussões também foram levadas a eventos de âmbito regional, como os Congressos Norte Nordeste de Terapia Ocupacional, ${ }^{55-57}$ e também de âmbito internacional, como os Congressos da Federação Mundial de Terapeutas Ocupacionais ${ }^{58-60}$ e o Congresso Argentino de Terapia Ocupacional. ${ }^{61}$

Houve ainda diversos trabalhos produzidos por grupos de pesquisa sediados nas universidades Federal de São Carlos, PUCCamp e USP/SP publicados em eventos fora do circuito exclusivo da categoria como Congressos Brasileiros de Extensão Universitária, ${ }^{62-64}$ । Simpósio Internacional do Adolescente, ${ }^{65}$ Seminário para Metodologia de Projetos de Extensão, ${ }^{66}$ entre outros.

A Terapia Ocupacional Social, em seu desenvolvimento como campo de conhecimentos e práticas específicos problematizou a noção de atividade, conforme apontado por, ${ }^{12}$ de modo a explorar as dimensões culturais a ela relacionadas, propondo intervenções contextualizadas no universo de saberes das comunidades ou grupos a que se destina, em um processo de constantes e mútuas descobertas a partir da interação com esses atores sociais e do contato direto com sua realidade sócio-histórica. 


\begin{abstract}
As atividades não possuem significados fixos; formam-se constantemente múltiplos significados que se sobrepõem. Elas são expressões das identidades e participam de processos que formam identidades. Por serem um processo relacional, são também um processo político, e, nesse processo, torna-se imperativo para o terapeuta ocupacional desenvolver atividades culturalmente pertinentes, pois se trata de compreender como as atividades mais valorizadas são percebidas na comunidade e como estão articuladas aos símbolos chave que formam as identidades. ${ }^{67}$
\end{abstract}

Outra importante questão trazida pelos pesquisadores desse campo refere-se à interpretação das demandas que são compreendidas em íntima relação com o cotidiano e com os valores dos indivíduos e de suas comunidades. Além de serem consideradas como são manifestadas sem que sejam hierarquizadas com base em conhecimentos técnicos ou valorações individuais do profissional.

Os grupos populacionais com os quais os terapeutas ocupacionais têm atuado também vêm se diversificando. Podem-se encontrar trabalhos em comunidades rurais, em sociedades indígenas, com população adulta em situação de rua, com movimentos sociais rurais e urbanos.

As intervenções são pautadas nas noções de cidadania, conquista de direitos, autonomia em diálogos interculturais. Elas têm ocorrido 
em equipamentos sociais públicos, em organizações não-governamentais, enfim, em toda a complexa malha assistencial do terceiro setor, além de contextos comunitários. Muitas publicações trouxeram também relatos de experiências de participação em fóruns de discussão e conselhos de direitos em que estavam pautados debates acerca de políticas públicas.

Barros $^{68}$ ressalta a importância de uma formação profissional capaz de instrumentalizar o técnico para atuar na mediação de conflitos sociais e em processos de negociação cultural, ${ }^{68}$ e também que possa situá-lo a cerca das políticas socioassistenciais, contribuindo para o desenvolvimento de senso crítico em relação ao conteúdo e operacionalização das mesmas. Nesse contexto, conhecer o Sistema Único da Assistência Social (SUAS) torna-se fundamental já que é por meio dele que está prevista a efetivação da Lei Orgânica da Assistência Social (Lei 8.742, de 28 de dezembro de 1990).

Outro aspecto referente à formação com o qual tem se deparado atualmente os profissionais do campo é a inexistência de programas de pósgraduação latu sensu na área e que, na opinião de Galheigo, ${ }^{69}$ "tem fragilizado a inserção profissional", e "o mestrado acaba sendo quase que a única e limitada opção de continuidade da formação para os terapeutas ocupacionais que trabalham no campo social". 69

A inquietação com as injustiças sociais e com as desigualdades cronicamente presentes em sociedades como a brasileira, o reconhecimento do papel político e ideológico da ação técnica, a recusa em atuar na medicalização dos conflitos sociais e o reconhecimento de que os conhecimentos específicos eram insuficientes e vinham se mostrando ineficazes para lidar com as questões postas acima fizeram com que 
terapeutas ocupacionais se laçassem na busca por formas de enfrentamento dessas situações e se permitissem o desafio de pensar uma atuação fora dos conhecidos campos de atuação profissional.

Foi uma jornada em que, para descobrir as alteridades e as múltiplas identidades de pessoas com cultura e cotidiano tão diferentes das dos técnicos - cuja origem era, e ainda é, predominantemente de classe média -, foi preciso enfrentar o não-saber, conhecer o saber do outro e assim engendrar conjuntamente formas de lidar com as contradições que se apresentavam.

A Terapia Ocupacional, ao desenvolver uma abordagem social, preconiza que os técnicos não devam chegar a esse campo como "colonizadores", do alto de um pretenso poder e saber técnico-científico, definindo unilateralmente "as" formas adequadas de enfrentamento dos conflitos presentes. É importante ressaltar que, antes dos profissionais se voltarem para o chamado campo social, grupos e populações já lidavam com seus dilemas cotidianos.

Desse modo, pautados no pensamento de Paulo Freire e na discussão sobre a noção de alteridade vinda da Antropologia, a proposta é tornar-se também um agente do campo social interagindo e atuando em seu interior sabendo-se diferente, mas capaz de dialogar e negociar.

A terapia ocupacional social se caracteriza por uma intervenção pautada na manutenção da inter-relação entre PESSOA - GRUPO - ATIVIDADE - MEIO AMBIENTE (sociedade/ cultura/ natureza). Esse princípio é tecido em dialogias múltiplas. ${ }^{70}$ 
Por fim, análise do conjunto mais amplo de publicações de Terapia Ocupacional Social, aquele presente nos CBTOs, evidenciou as contribuições advindas de pesquisas e programas de extensão coordenados por autores/docentes de três universidades paulistas (UFSCar, USP/SP e PUCCamp $^{* * *}$ ), nas definições que constituem o arcabouço estrutural do campo como: a população-alvo e os grupos sociais abordados, a diferenciação metodológica do universo das práticas em saúde e os eixos de atuação pautados nos conceitos de autonomia, cidadania e diretos.

A partir do levantamento bibliográfico, podem-se perceber as principais questões que perpassaram o desenvolvimento da Terapia Ocupacional Social, as contribuições trazidas pelos autores que escrevem sobre a constituição do mesmo, conforme descrito anteriormente, bem como as posições que ocupam nesse campo como docentes/pesquisadores.

\footnotetext{
${ }^{* * *}$ A pesquisadora Sandra Maria Galheigo, referência para o campo na PUCCamp, desde 2006 pertence aos quadros docentes da USP/SP.
} 


\section{Considerações finais}

Pesquisar o desenvolvimento da Terapia Ocupacional Social através da produção científica paulista constituiu-se num desafio inicialmente de tamanho insuspeito, pois em um primeiro momento parecia que a produção era ainda reduzida e que a abordagem de questões sociais encontrava-se restrita a autores ou profissionais do campo social.

Desse modo, procedeu-se a análise dos trabalhos dos congressos a fim de conhecer os profissionais que se encontravam envolvidos no campo social, onde atuavam, com que grupos populacionais, quais as metodologias utilizadas e os pressupostos teóricos que tinham como referência.

A idéia acerca das dimensões da produção relacionada ao campo social foi sendo revista na medida em que se verificou a existência de um conjunto de 105 trabalhos apresentados nos congressos brasileiros, de aproximadamente 50 publicações entre artigos, capítulos de livro e dissertação - vale lembrar que foram contabilizadas apenas as publicações de autores paulistas - sem contar com os trabalhos publicados em outros congressos relacionados ou não à Terapia Ocupacional.

O número de publicações de Terapia Ocupacional Social revelouse maior do que o esperado, porém, em relação ao volume de publicações da Terapia Ocupacional como um todo parece ainda pequeno. Recorrendo aos dados tabulados dos congressos brasileiros pode-se notar que os trabalhos de Terapia Ocupacional Social representaram somente $6 \%$ do conjunto de trabalhos apresentados nos últimos seis congressos. Contudo, quando verificado o índice de crescimento da área, considerando os 10 anos em que 
se realizaram os congressos pesquisados, constatou-se uma velocidade de crescimento mais que o dobro superior a da Terapia Ocupacional como um todo.

Os trabalhos dos congressos revelaram também que a preocupação com problemáticas envolvendo injustiças sociais, descriminações étnico-culturais, assim como com a produção de desigualdades também é expressa por parte de terapeutas ocupacionais que utilizam outras metodologias de intervenção não identificadas com abordagens sociais. Foram encontrados trabalhos de profissionais atuando no campo social utilizando referenciais de saúde e métodos clínicos, assim como atuações pautadas no desenvolvimento neuropsicomotor ou em abordagens de saúde coletiva.

Grande parte do trabalho foi analisar as diferentes abordagens descritas a fim de identificar aquelas que apresentavam enfoque social e diferencia-las das que faziam interface com o campo ou mesmo tomavam questões sócio-culturais mediante lógicas clínicas. A presença de trabalhos com as características acima demonstrou o quanto as problemáticas relacionadas às desigualdades sociais e a pobreza vêm também fazer parte da atenção dos técnicos de saúde e sob perspectivas bastante diversas.

Também tornou-se evidente a estreita relação entre o desenvolvimento experimentado pela Terapia Ocupacional Social e a realização de programas de extensão universitária ou serviços oferecidos a população associados ao ensino de graduação no campo social, pois houve quantidade considerável de trabalhos apresentados nos congressos a partir de experiências dessa natureza. 
Parte importante da produção bibliográfica relacionada ao campo provém de ações que articulam ensino específico a programas de extensão, os quais servem como mediação do contato dos estudantes com os grupos sociais atendidos, bem como com a rede sócio-assistencial existente e com as políticas de âmbito social organizadas como parte do Sistema Único da Assistência Social.

No que se refere à teorização acerca de aspectos relacionados à sua constituição enquanto campo de atuação para terapeutas ocupacionais, a Terapia Ocupacional Social tem recebido contribuições predominantemente de autores paulistas, notadamente daqueles ligados ao Projeto Metuia, atualmente único grupo voltado exclusivamente ao desenvolvimento de pesquisas e metodologia específica de intervenção social, sendo responsável por grande parte das publicações do campo. Isso parece se dar devido ao fato de que estratégias de produção intelectual grupal dinamizam o processo de reflexão e sistematização de experiências e ampliam o alcance de projetos de intervenção.

Estudando o desenvolvimento do campo da Terapia Ocupacional Social ocorrido nos últimos vinte anos, desde que começaram a surgir as primeiras publicações a denominá-lo desta forma até o momento atual, foi possível perceber seu movimento de progressiva estruturação, a maturação de proposições técnicas e questões inicialmente colocadas, bem como o surgimento de novos desafios que vem se impondo a consolidação do campo tanto no cenário acadêmico, quanto no cotidiano profissional.

Mediante análise da produção bibliográfica encontrada, nos pareceu que o movimento de incorporação do social enquanto questão, 
também para os profissionais terapeutas ocupacionais, foi ressoando de formas diferentes no ensino de graduação (notadamente naquele praticado nas universidades paulistas) e no cotidiano de trabalho dos terapeutas que atuam no campo social.

Destes dois contextos, sobretudo do meio universitário, surgiram contribuições que vêm dando corpo ao desenvolvimento de tecnologias de intervenção social por meio das quais o terapeuta ocupacional vem interagindo no campo como operador social de mudança juntamente com os atores e grupos sociais que lá estão.

Tendo em vista o processo de desenvolvimento deste campo na profissão ao longo das últimas 2 décadas pode-se dizer que, atualmente, encontra-se constituído de agentes que nele atuam e participam (profissionais, estudantes, grupos sociais diversos, instituições de ensino/pesquisa, movimentos sociais, instituições de assistência), de proposições de intervenção definidas (calcadas nas noções de cidadania, direitos humanos e negociações interculturais) e de pressupostos teóricos próprios (resultantes da articulação de saberes específicos da Terapia Ocupacional com os conhecimentos sócioantropológicos).

Foi possível ainda, identificar alguns dos aspectos que vem contribuindo, ou que podem vir a contribuir ainda mais, para a expansão do mesmo, como a ampliação de programas de pós - graduação estrito-senso e a criação de programas lato senso. Possibilidades que atualmente podem ser vislumbradas em função do acúmulo de conhecimentos já estruturados. 
Existem também certas dificuldades encontradas para a ampliação da Terapia Ocupacional Social como a baixa remuneração que os trabalhadores sociais enfrentam, e que tem dificultado a inserção profissional.

Ao longo das duas décadas em que a Terapia Ocupacional Social vem se desenvolvendo, as questões sociais brasileiras continuam guardando as mesmas semelhanças com aquelas identificadas pelos primeiros terapeutas ocupacionais a atuar no campo social. Este foi um período pequeno para que se processassem mudanças significativas nas problemáticas geradoras de desigualdades sociais, pobreza, distribuição desigual de oportunidades e conflitos culturais vividos nos país. Porém, nesse pequeno período foi possível para a Terapia Ocupacional desenvolver formas concretas de abordagem das questões sociais e das demandas vivenciadas por grupos em situação de vulnerabilidade.

As questões sociais brasileiras ainda são as mesmas, mas os terapeutas ocupacionais não se encontram da mesma forma diante delas. 


\section{ANEXO A - LISTA DOS 105 TRABALHOS SELECIONADOS NOS CONGRESSOS BRASILEIROS DE TERAPIA OCUPACINAL}

\section{Congresso Brasileiro de Terapia Ocupacional - Belo Horizonte/MG - 1997.}

\section{COMUNICAÇÃO ORAL}

1. Galheigo SM. Educação e Trabalho: velhos dilemas, novos rumos nos programas de profissionalização para adolescentes. Anais do VI Congresso Brasileiro, IV Simpósio Latino Americano de Terapia Ocupacional. 1997 Out. 28-31; Belo Horizonte. Belo Horizonte: Associação dos Terapeutas Ocupacionais de Minas Gerais; 1997. v. 1. p. 158-160.

\section{Congresso Brasileiro de Terapia Ocupacional - Águas de Lindóia/SP - 1999.}

\section{COMUNICAÇÕES ORAIS}

1. Galluzzi AM. Transitando na Rua: Atividades e Intervenção Social. Águas de Lindóia: Programas e Resumos do VI Congresso Brasileiro de Terapia ocupacional. 1999 Set. 28-Out. 01; Águas de Lindóia, São Paulo: 1999. p. 23.

2. Galheigo SM. Repensando o lugar do social: a constituição de um campo de conhecimento em terapia ocupacional. Programas e Resumos do VI Congresso Brasileiro de Terapia ocupacional. 1999 Set. 28-Out. 01; Águas de Lindóia, São Paulo: 1999. p. 24.

3. Barros DD, Lopes RE, Ghirardi MIG. Terapia Ocupacional e Sociedade. Programas e Resumos do VI Congresso Brasileiro de Terapia ocupacional. 1999 Set. 28-Out. 01; Águas de Lindóia, São Paulo: 1999. p. 23.

4. Barros DD, Lopes RE, Galvani D, Malfitano APS. Terapia Ocupacional e Ações Territoriais: Crianças e Adolescentes em Processos de Rupturas de Redes Sociais de Suporte. Programas e Resumos do VI Congresso Brasileiro de Terapia ocupacional. 1999 Set. 28-Out. 01; Águas de Lindóia, São Paulo: 1999. p. 24.

5. Galheigo SM, Takeiti BA, Harder J, Catalano LU, Jorge R, Silva VC. Adolescência, Cidadania e Subjetividade: um estudo sobre a atenção ao adolescente em situação de risco pessoal e social na cidade de 
Campinas. Programas e Resumos do VI Congresso Brasileiro de Terapia ocupacional. 1999 Set. 28-Out. 01; Águas de Lindóia, São Paulo: 1999. p. 24.

6. Delorenzo GAS. Semana dos encontros: proposta de uma metodologia de abordagem indtitucional em meio aberto com adolescentes infratores. Programas e Resumos do VI Congresso Brasileiro de Terapia ocupacional. 1999 Set. 28-Out. 01; Águas de Lindóia, São Paulo: 1999. p. 40.

7. El-Khatib U, Bragatto SCO. O Estatuto da criança e do adolescente: discutindo as perspectivas de intervenção da terapia ocupacional com a criança e o adolescente em situação de risco pessoal e social. Programas e Resumos do VI Congresso Brasileiro de Terapia ocupacional. 1999 Set. 28-Out. 01; Águas de Lindóia, São Paulo: 1999. p. 40.

8. Almeida SC, Gonçalves LR.; Rocha FD. Terapia ocupacional atrás das grades. Programas e Resumos do VI Congresso Brasileiro de Terapia ocupacional. 1999 Set. 28-Out. 01; Águas de Lindóia, São Paulo: 1999. p. 41.

\section{PÔSTERES}

9. Akemi B, Penteado CML, Delorenzo GAS. Grupo de Jornal - Projeto Metuia. Programas e Resumos do VI Congresso Brasileiro de Terapia ocupacional. 1999 Set. 28-Out. 01; Águas de Lindóia, São Paulo: 1999. p. 57.

10.Licco AL. Penteado CML, Delorenzo GAS. Espaço só para criançasProjeto Metuia. Programas e Resumos do VI Congresso Brasileiro de Terapia ocupacional. 1999 Set. 28-Out. 01; Águas de Lindóia, São Paulo: 1999. p. 58.

11. Oliveira AM, Barros, DD, Galluzzi AM. A terapia ocupacional e a área social: vivendo e aprendendo. Programas e Resumos do VI Congresso Brasileiro de Terapia ocupacional. 1999 Set. 28-Out. 01; Águas de Lindóia, São Paulo: 1999. p. 58.

12. Almeida MM, El-Khatib U. Caracterização e diagnóstico das condições do abrigo infantil de São Carolos. Programas e Resumos do VI Congresso Brasileiro de Terapia ocupacional. 1999 Set. 28-Out. 01; Águas de Lindóia, São Paulo: 1999. p. 57.

13. Delorenzo GAS. "Só para mulheres" grávidas e jovens mães: a prevenção enquanto fio condutor do olhar do terapeuta ocupacional. Programas e Resumos do VI Congresso Brasileiro de Terapia ocupacional. 1999 Set. 28-Out. 01; Águas de Lindóia, São Paulo: 1999. p. 59. 


\section{Congresso Brasileiro de Terapia Ocupacional - Porto Alegre/RS - 2001.}

\section{COMUNICAÇÕES ORAIS}

1. Reis TAM, Galvani D. Terapia Ocupacional no Campo Social: relato de uma experiência com população adulta em situação de rua. Anais do VII Congresso Brasileiro de Terapia Ocupacional; 2001 Out. 2-5; Porto Alegre, Rio Grande do Sul; 2001.

2. Malfitano APS, Barros DD, Galluzzi AM, Galvani; Lopes RE. Projeto casarão: possibilidades e Limites no Trabalho Comunitário com Crianças. Anais do VII Congresso Brasileiro de Terapia Ocupacional; 2001 Out. 2-5; Porto Alegre, Rio Grande do Sul; 2001.

3. Costa MC. Arte de Rua e Terapia Ocupacional: problematizando os desafios da sociedade neoliberal. Anais do VII Congresso Brasileiro de Terapia Ocupacional; 2001 Out. 2-5; Porto Alegre, Rio Grande do Sul; 2001.

4. Moreira CEFAA. A terceira margem do rio - programa de oficina sócioeducativa - inclusão ou exclusão social? Anais do VII Congresso Brasileiro de Terapia Ocupacional; 2001 Out. 2-5; Porto Alegre, Rio Grande do Sul; 2001.

5. Alvarinho E, Kovelis $P$, Formagio $S$. Tramando mudanças: a idéia de trabalho cooperado e a prática da inclusão. Anais do VII Congresso Brasileiro de Terapia Ocupacional; 2001 Out. 2-5; Porto Alegre, Rio Grande do Sul; 2001.

6. Lopes RE, Barros DD, Galluzzi AM, Galvani D, Malfitano APS. Projeto Casarão: uma Parceria que se Constrói Dia-a-dia. Anais do VII Congresso Brasileiro de Terapia Ocupacional; 2001 Out. 2-5; Porto Alegre, Rio Grande do Sul; 2001.

7. Góes LC, Antunes RAB, Lima CD, Maciel KA, Nicolau EM. Terapia Ocupacional e geração de renda - um trabalho de sensibilização. Anais do VII Congresso Brasileiro de Terapia Ocupacional; 2001 Out. 2-5; Porto Alegre, Rio Grande do Sul; 2001.

8. Ghirardi MIG. Trabalho cooperado e deficiência: contribuições da terapia ocupacional. Anais do VII Congresso Brasileiro de Terapia Ocupacional; 2001 Out. 2-5; Porto Alegre, Rio Grande do Sul; 2001. 
9. Gigante, M. P. Barfknecht, K. Geração/ Poá à incubadora de grupos de autogestão. Anais do VII Congresso Brasileiro de Terapia Ocupacional; 2001 Out. 2-5; Porto Alegre, Rio Grande do Sul; 2001.

10. Nicolau SM. A terapia ocupacional e a economia solidária: uma parceria promissora. Anais do VII Congresso Brasileiro de Terapia Ocupacional; 2001 Out. 2-5; Porto Alegre, Rio Grande do Sul; 2001.

11. Tissi MC, Abreu CBB, Aoki M, Bortoli MNSF, Caldeira VA, Candolo ME, Catini TA, Ciccone AMR, Leonardi KV, Rizzo RL. Implantação da brinquedoteca comunitária: uma possibilidade de participação social de crianças com deficiência. Anais do VII Congresso Brasileiro de Terapia Ocupacional; 2001 Out. 2-5; Porto Alegre, Rio Grande do Sul; 2001.

12. Oliver FC, Tissi MC, Camargo J. Oficina do Fazer: criando e ampliando processos de validação a partir de atividades de geração de renda. Anais do VII Congresso Brasileiro de Terapia Ocupacional; 2001 Out. 2-5; Porto Alegre, Rio Grande do Sul; 2001.

13. Publio AS. Menina $X$ mulher: uma reflexão sobre a adolescência em situação de risco social. Anais do VII Congresso Brasileiro de Terapia Ocupacional; 2001 Out. 2-5; Porto Alegre, Rio Grande do Sul; 2001.

\section{PÔSTERES}

14. Galluzzi AM, Souza C, Benetti DA, Souza JV, Ometto, JMA, Vieira MS, Rocha NO, Rocha PR. Reciclart Casarão: Recriando o Viver com Arte. Anais do VII Congresso Brasileiro de Terapia Ocupacional; 2001 Out. 2-5; Porto Alegre, Rio Grande do Sul; 2001.

15. Takeiti BA, O Contar e o Repensar a Própria História: uma Metodologia de Investigação e Intervenção - Projeto Metuia. Anais do VII Congresso Brasileiro de Terapia Ocupacional; 2001 Out. 2-5; Porto Alegre, Rio Grande do Sul; 2001.

16. Galvani D, Barros DD, Galluzzi AM, Lopes RE, Malfitano APS, Silva CR. Projeto Casarão - Centro de Cultura e Convivência Celso Garcia. Anais do VII Congresso Brasileiro de Terapia Ocupacional; 2001 Out. 2-5; Porto Alegre, Rio Grande do Sul; 2001.

17. Alvarinho E, Kovelis $P$, Formagio $S$. Produzindo a diferença: a cooperativa Tramart no mercado de artesanato. Anais do VII Congresso Brasileiro de Terapia Ocupacional; 2001 Out. 2-5; Porto Alegre, Rio Grande do Sul; 2001. 
18. Clareto LF, Galheigo SM, Vilas Boas FD, Allegretti MM; Silva SM, Pensando a rede de proteção especial: um estudo sobre a atenção à criança em situação de risco pessoal e social na cidade de Campinas. Anais do VII Congresso Brasileiro de Terapia Ocupacional; 2001 Out. 2-5; Porto Alegre, Rio Grande do Sul; 2001.

19. Tissi MC. Território em busca de utopia. Anais do VII Congresso Brasileiro de Terapia Ocupacional; 2001 Out. 2-5; Porto Alegre, Rio Grande do Sul; 2001.

20. Tissi MC, Santos AAA, Brito CH, Pereira CCP, Meira LMOS, Silva MR, Pinheiro MS. Terapia Ocupacional junto à juventude: a emergência da área social. Anais do VII Congresso Brasileiro de Terapia Ocupacional; 2001 Out. 2-5; Porto Alegre, Rio Grande do Sul; 2001.

21. Renzo MPD, Fernández ZF. Terapia ocupacional: relato da atuação no projeto agente jovem de desenvolvimento social e humano de São José do Rio Preto. Anais do VII Congresso Brasileiro de Terapia Ocupacional; 2001 Out. 2-5; Porto Alegre, Rio Grande do Sul; 2001.

22. Barros ACBG, Correa VAC. Desvendando os brinquedos e as brincadeiras das crianças do Aurá - PA. Anais do VII Congresso Brasileiro de Terapia Ocupacional; 2001 Out. 2-5; Porto Alegre, Rio Grande do Sul; 2001.

23. Antunes DC, Borini MLO. Envelhecimento compartilhado: grupos comunitários - uma atuação possível em terapia ocupacional. Anais do VII Congresso Brasileiro de Terapia Ocupacional; 2001 Out. 2-5; Porto Alegre, Rio Grande do Sul; 2001.

24. Soares EC, Silva MEO, Pessoa CKL. Geração de renda alternativa na comunidade numa abordagem terapêutica ocupacional. Anais do VII Congresso Brasileiro de Terapia Ocupacional; 2001 Out. 2-5; Porto Alegre, Rio Grande do Sul; 2001.

25. Conti J, Delorenzo GAS. Relato de uma experiência: atelier de atividades com adolescentes. Anais do VII Congresso Brasileiro de Terapia Ocupacional; 2001 Out. 2-5; Porto Alegre, Rio Grande do Sul; 2001.

26. Basic MVA. Terapia ocupacional junto á mulheres que sofreram violência doméstica. Anais do VII Congresso Brasileiro de Terapia Ocupacional; 2001 Out. 2-5; Porto Alegre, Rio Grande do Sul; 2001. 


\section{Congresso Brasileiro de Terapia Ocupacional - Foz do Iguaçu/Pr - 2003.}

\section{PAINÉIS}

1. Santos TFS, Solfa GC, Almeida IS. A Intervenção da terapia ocupacional na formação de grupo com adolescentes em espaço aberto colaborando na efetivação de políticas públicas. Anais do VIII Congresso de Terapia Ocupacional; 2003 Jun. 2-6; Foz do Iguaçu, Paraná; 2003. № 120.

2. Kayser AB, Siegmann C, Mendonça IJ, Ros JCS. Projeto de terapia ocupacional - prática social. Anais do VIII Congresso de Terapia Ocupacional; 2003 Jun. 2-6; Foz do Iguaçu, Paraná; 2003. № 098.

3. Lopes RE, Borba PLO. Mulheres em Situação de rua: percursos e rupturas sob a ótica da terapia ocupacional. Anais do VIII Congresso de Terapia Ocupacional; 2003 Jun. 2-6; Foz do Iguaçu, Paraná; 2003. Nº 094.

4. Moreno AF. Terapia ocupacional frente al trabajo infantil en Colombia. Anais do VIII Congresso de Terapia Ocupacional; 2003 Jun. 2-6; Foz do Iguaçu, Paraná; 2003. № 083.

5. Galheigo SM. O trabalho em abrigos para crianças e adolescentes: considerações acerca do papel do terapeuta ocupacional. Anais do VIII Congresso de Terapia Ocupacional; 2003 Jun. 2-6; Foz do Iguaçu, Paraná; 2003. № 068.

6. Ferriotti ML, Siqueira CAA, Garcia MN. Colcha de retalhos: do setting terapêutico à praça pública. Anais do VIII Congresso de Terapia Ocupacional; 2003 Jun. 2-6; Foz do Iguaçu, Paraná; 2003. № 095.

7. Sathler ARQ, Silva, LAF. O esporte como atividade ocupacional, aplicado numa ambiência comunitária de baixa renda e sob risco social, localizada no Rio de Janeiro, Brasil. Anais do VIII Congresso de Terapia Ocupacional; 2003 Jun. 2-6; Foz do Iguaçu, Paraná; 2003. № 130.

8. Carvalho ALL. A terapia ocupacional na reinserção profissional do preso do sistema penal. Anais do VIII Congresso de Terapia Ocupacional; 2003 Jun. 2-6; Foz do Iguaçu, Paraná; 2003. № 085.

\section{PÔSTERES}

9. Delorenzo GAS, Mazzoti LS, Galheigo SM. Atelier de terapia ocupacional - um espaço de criação e vivência cotidiana. Anais do VIII Congresso de Terapia Ocupacional; 2003 Jun. 2-6; Foz do Iguaçu, Paraná; 2003. № 103. 
10. Pimentel FA, Camargo EB, Galheigo SM. Os centros de resocialização (centro de recuperação de presidiários): um novo campo de atuação do terapeuta ocupacional. Anais do VIII Congresso de Terapia Ocupacional; 2003 Jun. 2-6; Foz do Iguaçu, Paraná; 2003. № 069.

11. Clareto LF, Galheigo SM. Experiência ocupacional, cotidiano, subjetividade: um estudo comparativo entre adolescentes em medida de liberdade assistida e em programa de educação para e pelo trabalho. Anais do VIII Congresso de Terapia Ocupacional; 2003 Jun. 2-6; Foz do Iguaçu, Paraná; 2003. № 061.

12. Alegretti MM, Galheigo SM. A rede de apoio social do adolescente autor de ato infracional e de sua família. Anais do VIII Congresso de Terapia Ocupacional; 2003 Jun. 2-6; Foz do Iguaçu, Paraná; 2003. № 060.

13. Teixeira BC, Pelerosi S. Projeto aquarela e casa das meninas: intervenções de terapia ocupacional no campo social. Anais do VIII Congresso de Terapia Ocupacional; 2003 Jun. 2-6; Foz do Iguaçu, Paraná; 2003. № 020.

14. Oliver FC, Tissi MC, Aoki M, Rodrigues EFV, Ferreira T, Almeida M. Oficinas de trabalho: sociabilidade ou renda? Anais do VIII Congresso de Terapia Ocupacional; 2003 Jun. 2-6; Foz do Iguaçu, Paraná; 2003. № 105.

15. Ferreira CVP, Guterres C, Barfknecht KS, Senna L, Salvador L, Bertuol M. Geração / POÁ. Anais do VIII Congresso de Terapia Ocupacional; 2003 Jun. 2-6; Foz do Iguaçu, Paraná; 2003. № 016.

\section{Congresso Brasileiro de Terapia Ocupacional - Recife/PE - 2005}

\section{CONFERÊNCIAS}

1. Galvani D, Barros DD, Almeida MC, Vecchia TC, Reis TAM.Terapia Ocupacional Social e a Experiência com a População em Situação de Rua em São Paulo: Formação e Organização Política. Anais do IX Congresso Brasileiro de Terapia Ocupacional; 2005 Set. 27-30; Recife, Pernambuco; 2005.

2. Barros DD, Ghirardi MIG, Lopes RE, Galheigo S. M. Terapia ocupacional sem fronteiras: comparando conceitos internacionais para uma análise engajada. Anais do IX Congresso Brasileiro de Terapia Ocupacional; 2005 Set. 27-30; Recife, Pernambuco; 2005. 


\section{CURSO PRÉ- CONGRESSO}

3. Galheigo SM, Barros DD, Lopes RE. A Terapia Ocupacional no Campo Social: Políticas e Fundamentos Teórico-metodológicos. Curso précongresso ministrado no IX Congresso Brasileiro de Terapia Ocupacional; 2005 Set. 27-30; Recife, Pernambuco; 2005.

\section{MESAS REDONDAS}

4. Malfitano APS. Terapia Ocupacional social: campos e núcleos de intervenção. Programas e Resumos do IX Congresso Brasileiro de Terapia Ocupacional; 2005 Set. 27-30; Recife, Pernambuco; 2005.

5. Galheigo SM, Takeiti BA. Adolescência, reciprocidade e ação territorial: o teatro como estratégia de ação na terapia ocupacional. Programas e Resumos do IX Congresso Brasileiro de Terapia Ocupacional; 2005 Set. 27-30; Recife, Pernambuco; 2005.

6. Aoki M, Oliver FC, Nicolau EM, Maria Cristina Tissi. Brincando na rua. Programas e Resumos do IX Congresso Brasileiro de Terapia Ocupacional; 2005 Set. 27-30; Recife, Pernambuco; 2005.

7. Gontijo DT, Medeiros M. O significado da maternidade para adolescentes com experiência de vida nas ruas: implicações para a terapia ocupacional. Programas e Resumos do IX Congresso Brasileiro de Terapia Ocupacional; 2005 Set. 27-30; Recife, Pernambuco; 2005.

8. Almeida MM. Grupo de terapia ocupacional: um espaço para produção de vida de jovens egressos de medidas sócio-educativas. Programas e Resumos do IX Congresso Brasileiro de Terapia Ocupacional; 2005 Set. 27-30; Recife, Pernambuco; 2005.

9. Projeto Agente jovem: um estudo de caso de grupo de jovens em desenvolvimento de seu protagonismo. Francine de Lurdes Antonietti, Uiara Cristina Viana Danelutti e Sandra Maria Galheigo. IX Congresso Brasileiro de Terapia Ocupacional; 2005 Set. 27-30; Recife, Pernambuco; 2005.

\section{COMUNICAÇÕES COORDENADAS}

10. Projeto agente jovem: a perspectiva dos usuários. Gabrielle Ferreira Fraimann, Débora Porto Maciel e Sandra Maria Galheigo. Projeto Agente Jovem e a Ação da Terapia Ocupacional. Programas e Resumos do IX Congresso Brasileiro de Terapia Ocupacional; 2005 Set. 27-30; Recife, Pernambuco; 2005. 
11. Malfitano APS, Lopes, RE, Borba PLO. A. Fazer para quê? Oficina de atividades inserida no cotidiano de um abrigo para adolescentes em situação de rua. Programas e Resumos do IX Congresso Brasileiro de Terapia Ocupacional; 2005 Set. 27-30; Recife, Pernambuco; 2005.

12. Tamura RA, Botteon LM, Galheigo SM. Projeto agente jovem: a perspectiva dos gestores. Programas e Resumos do IX Congresso Brasileiro de Terapia Ocupacional; 2005 Set. 27-30; Recife, Pernambuco; 2005.

13. Costa CO, Dorneles P. Galpão de reciclagem: buscando e entendendo a inclusão social através do trabalho com lixo. Programas e Resumos do IX Congresso Brasileiro de Terapia Ocupacional; 2005 Set. 27-30; Recife, Pernambuco; 2005.

14. Almeida MM. Pensando sobre o papel da terapia ocupacional: 0 ato infracional, o trabalho infantil, o trabalho em situação de rua, o trabalho juvenil são estratégias que promovem ou não a "liberdade" do jovem? Programas e Resumos do IX Congresso Brasileiro de Terapia Ocupacional; 2005 Set. 27-30; Recife, Pernambuco; 2005.

15. Almeida MM. O jornal e o vídeo como meio de expressão de jovens internados na unidade educacional na Febem de Ribeirão Preto. Programas e Resumos do IX Congresso Brasileiro de Terapia Ocupacional; 2005 Set. 27-30; Recife, Pernambuco; 2005.

16. Lopes RE, Malfitano APS, Borba PLO. A interface vídeo/imagem como recurso terapêutico - ocupacional no trabalho com adolescentes. Programas e Resumos do IX Congresso Brasileiro de Terapia Ocupacional; 2005 Set. 27-30; Recife, Pernambuco; 2005.

17. Koketsu AY, Lopes RE, Reis TAM. Na fronteira entre o social e a saúde mental: relato de uma experiência de terapia ocupacional. Programas e Resumos do IX Congresso Brasileiro de Terapia Ocupacional; 2005 Set. 27-30; Recife, Pernambuco; 2005.

\section{PÔSTERES}

18. Garcia AG, Recco DW Vecchia TC, Coelho VS, Barros DD. Projeto Casa Rosa: Experiência de Discentes na Terapia Ocupacional em uma Comunidade Rural. Anais do IX Congresso Brasileiro de Terapia Ocupacional; 2005 Set. 27-30; Recife, Pernambuco; 2005.

19. Grazioli GR, Bernardes TB, Galheigo SM. Ações preventivas contra a violência: perspectivas dos adolescentes e profissionais de um programa comunitário. Anais do IX Congresso Brasileiro de Terapia Ocupacional; 2005 Set. 27-30; Recife, Pernambuco; 2005. 
20. Koketsu AY, Lopes RE, Reis, TAM. (Re)construindo redes sociais de suporte: na rua e na vida. Anais do IX Congresso Brasileiro de Terapia Ocupacional; 2005 Set. 27-30; Recife, Pernambuco; 2005.

21. Balaguer $A L$, Oliveira MC. A implantação de um estágio de terapia ocupacional nos processos sociais em um centro social urbano de Salvador- BA. Anais do IX Congresso Brasileiro de Terapia Ocupacional; 2005 Set. 27-30; Recife, Pernambuco; 2005.

\section{Congresso Brasileiro de Terapia Ocupacional - Goiânia/GO - 2007}

\section{APRESENTAÇÕES ORAIS}

1. Lopes RE; Malfitano APS, Oliveira PL. Problematizando a atuação do terapeuta ocupacional nas organizações não governamentais. Anais $X$ Congresso Brasileiro de Terapia Ocupacional; 2007 Maio 15-18; Goiânia, Goiás; 2007.

2. Cunha CD, Botteon LM. Refletindo a terapia ocupacional social a partir da complexidade. Anais X Congresso Brasileiro de Terapia Ocupacional; 2007 Maio 15-18; Goiânia, Goiás; 2007.

3. Petrokas, RC, Barros DD. Atividades nas casas de convivência de atenção à população adulta em situação de rua: estudo de caso. Anais $X$ Congresso Brasileiro de Terapia Ocupacional; 2007 Maio 15-18; Goiânia, Goiás; 2007.

4. Malfitano APS, Braga IF, Silva KG, Mota NG. Promoção de direitos e mediação pela brincadeira: relato de uma experiência em terapia ocupacional social Anais X Congresso Brasileiro de Terapia Ocupacional; 2007 Maio 15-18; Goiânia, Goiás; 2007.

5. Malfitano APS, Adorno RCF. Infância e juventude e vivencias na ruas: processos de instituicionalização e políticas públicas. Anais $X$ Congresso Brasileiro de Terapia Ocupacional; 2007 Maio 15-18; Goiânia, Goiás; 2007.

6. Lopes RE, Malfitano AS. Exploração sexual comercial infanto-juvenil: relato de experiência em atividades no campo social com enfoque na intersetorialidade. Anais X Congresso Brasileiro de Terapia Ocupacional; 2007 Maio 15-18; Goiânia, Goiás; 2007. 
7. Silva DL, Santos ZR, Gontijo, Daniela Tavares. "Caminhando contra o vento sem lenço, sem documento": o cotidiano nas ruas para adultos em processo de desfiliação. Anais $X$ Congresso Brasileiro de Terapia Ocupacional; 2007 Maio 15-18; Goiânia, Goiás; 2007.

8. Achê P, Oliveira AS. A ocupação no MST: percepção e compreensão dos sem-terras: um olhar da terapia ocupacional. Anais $X$ Congresso Brasileiro de Terapia Ocupacional; 2007 Maio 15-18; Goiânia, Goiás; 2007.

\section{PÔSTERES}

9. Leão $A C A$, Cabral $C B$. Experiências de terapia ocupacional no processo de ressocialização de detentos. Anais $X$ Congresso Brasileiro de Terapia Ocupacional; 2007 Maio 15-18; Goiânia, Goiás; 2007.

10. Rodrigues MJM, Mendes MN. Experiências nas ruas: relato dos adolescentes do lar do menor. Anais X Congresso Brasileiro de Terapia Ocupacional; 2007 Maio 15-18; Goiânia, Goiás; 2007.

11.Tupich G. A dança utilizada pela terapia ocupacional no projeto social Gralha Azul. Anais X Congresso Brasileiro de Terapia Ocupacional; 2007 Maio 15-18; Goiânia, Goiás; 2007.

12. Lopes RE, Malfitano APS, Taketi BA. Juventude pobre, violência e a construção de espaços de participação pública: demandas para a terapia ocupacional. Anais X Congresso Brasileiro de Terapia Ocupacional; 2007 Maio 15-18; Goiânia, Goiás; 2007.

13. Aoki M, Oliver FC, Nicolau SM. Grupo de convivência na vida nova: implantação de um projeto de reabilitação com ênfase no território na periferia da cidade de São Paulo. Anais X Congresso Brasileiro de Terapia Ocupacional; 2007 Maio 15-18; Goiânia, Goiás; 2007.

14. Mende TD. A atuação do terapeuta ocupacional junto a uma cooperativa de portadores de HIV/Aids. Anais X Congresso Brasileiro de Terapia Ocupacional; 2007 Maio 15-18; Goiânia, Goiás; 2007.

15. Botteon LM, Cunhas CD. Terapia ocupacional social: exclusão como marco característico da demanda. Anais $X$ Congresso Brasileiro de Terapia Ocupacional; 2007 Maio 15-18; Goiânia, Goiás; 2007.

16. Takeiti BA, Petrokas R. Juventude nas trilhas das políticas públicas: novos campos de ação do terapeuta ocupacional nos centros de defesa dos direitos da criança e do adolescente (CEDECA). Anais X Congresso 
Brasileiro de Terapia Ocupacional; 2007 Maio 15-18; Goiânia, Goiás; 2007.

17. Santamaria LM, Petrokas R. Espaço vivencial de atividades: novos percursos com o adolescente autor de ato infracional. Anais $X$ Congresso Brasileiro de Terapia Ocupacional; 2007 Maio 15-18; Goiânia, Goiás; 2007.

18. Petrokas R, Goes AL. Donos da história: o teatro e a terapia ocupacional social nas ações territoriais de prevenção de violência. Anais $X$ Congresso Brasileiro de Terapia Ocupacional; 2007 Maio 15-18; Goiânia, Goiás; 2007.

\section{PALESTRAS}

19. Barros DD; Almeida MC. Cultura, redes sociais e terapia ocupacional. Anais X Congresso Brasileiro de Terapia Ocupacional; 2007 Maio 15-18; Goiânia, Goiás; 2007.

20. Galheigo SM. Campo social e terapia ocupacional: grandes temáticas contemporâneas em debate. Anais $\mathrm{X}$ Congresso Brasileiro de Terapia Ocupacional; 2007 Maio 15-18; Goiânia, Goiás; 2007.

21. Gerassi MI. Resignificando identidades: a minha trajetória no campo social. Anais X Congresso Brasileiro de Terapia Ocupacional; 2007 Maio 15-18; Goiânia, Goiás; 2007.

22. Barros DD. Dos riscos nas travessias de conceitos: palavras que velam conflitos. Anais X Congresso Brasileiro de Terapia Ocupacional; 2007 Maio 15-18; Goiânia, Goiás; 2007.

23. Barros DD. Desafios para uma formação de profissionais de saúde sensíveis à diversidade. Anais $X$ Congresso Brasileiro de Terapia Ocupacional; 2007 Maio 15-18; Goiânia, Goiás; 2007.

24. Lopes, Roseli Esquerdo. Terapia ocupacional social: a experiência do núcleo UFScar do projeto Metuia. Anais $\mathrm{X}$ Congresso Brasileiro de Terapia Ocupacional; 2007 Maio 15-18; Goiânia, Goiás; 2007.

25. Souto, Ana Cristina Fagundes. O uso das tecnologias de informação e comunicação com os jovens indígenas de Dourados, MS. Anais $X$ Congresso Brasileiro de Terapia Ocupacional; 2007 Maio 15-18; Goiânia, Goiás; 2007. 
26. Silva CR, Lopes RE. Violência, escola pública e terapia ocupacional: um campo de intervenção e pesquisa. Anais $X$ Congresso Brasileiro de Terapia Ocupacional; 2007 Maio 15-18; Goiânia, Goiás; 2007.

27. Vecchia T. Uma comunidade rural no sul de Minas Gerais: possibilidades de intervenção da terapia ocupacional social. Anais X Congresso Brasileiro de Terapia Ocupacional; 2007 Maio 15-18; Goiânia, Goiás; 2007.

28. Galvani D, Barros DD. Terapia ocupacional, redes sociais e adultos em situação de rua. Anais X Congresso Brasileiro de Terapia Ocupacional; 2007 Maio 15-18; Goiânia, Goiás; 2007.

29. Macedo MDC. Terapia ocupacional e a experiência com a comunidade Guarani da Aldeia Boa Vista. Anais X Congresso Brasileiro de Terapia Ocupacional; 2007 Maio 15-18; Goiânia, Goiás; 2007.

30. Lopes RE, Malfitano, APS, Taketi BA, Silva CR, Borba PLO. Juventude, violência e cidadania em grupos populares urbanos: intervenção coletiva e desenvolvimento social. Anais $X$ Congresso Brasileiro de Terapia Ocupacional; 2007 Maio 15-18; Goiânia, Goiás; 2007.

31. Santamaria LM. Liberdade assistida: uma trilha por novos caminhos, vínculos e histórias. Anais $X$ Congresso Brasileiro de Terapia Ocupacional; 2007 Maio 15-18; Goiânia, Goiás; 2007.

32. Malfitano APS. Políticas públicas e populações em situação de vulnerabilidade social: diálogos entre educação e saúde pública o campo social. Anais X Congresso Brasileiro de Terapia Ocupacional; 2007 Maio 15-18; Goiânia, Goiás; 2007.

33. Gontijo DT, Medeiros M. Juventude e gênero: discutindo subsídios para o planejamento de ações em terapia ocupacional junto a jovens em situação de rua. Anais X Congresso Brasileiro de Terapia Ocupacional; 2007 Maio 15-18; Goiânia, Goiás; 2007. 


\section{ANEXO B - HISTÓRICO DA PRODUÇÃO BIBLIOGRÁFICA DE AUTORES PAULISTAS DE TERAPIA OCUPACIONAL SOCIAL}

Fontes: Congressos Brasileiros de Terapia Ocupacional (1997-2007), Revista de Terapia Ocupacional da Universidade de São Paulo, Cadernos de Terapia Ocupacional da UFSCar, Base de dados SCIELO e Curriculum Lattes dos principais autores.

1990

1. Barros DD. Operadores de saúde na área social. Rev. De TO da USP. 1990;1(1):11-6.

1997

1. Galheigo SM. Da adaptação psicossocial construção do coletivo: a cidadania enquanto eixo. Rev. de Ciências Médicas da PUCCamp. 1997;6(2/3):105-8.

1998

1. El-Khatib U. Quando se trata de investigar "crianças e adolescentes em situação de risco pessoal e social"... Cad. de Ter. Ocup. UFSCar. 1998 Jan./Jun.; 7(1):1- 13.

1999

1. Barros DD, Ghirardi MIG, Lopes RE. Terapia ocupacional e sociedade.

Rev. Ter. Ocup. Univ. 1999 Maio/Dez.;10(2/3):69-74.

2000

1. El-Khatib U, Bragatto SCO. O estatuto da criança e do adolescente: perspectivas de intervenção da terapia ocupacional com a criança e o adolescente "em situação de risco pessoal e social. Cad. de Ter. Ocup. UFSCar. 2000;8(1):57-60.

2. Pimentel AM. Uma proposta de atuação do terapeuta ocupacional na atenção à criança e ao adolescente nas unidades da fundação cidade mãe. Rev. Ter. Ocup. Univ.. 2000; Maio/Dez.11(2/3):95-100.

3. Oliver FC, Barros DD, Medeiros H, Paganizzi L. La función social: diálogo entre colegas (Brasil y Argentina) acerca de la función social de la Terapia Ocupacional. Materia Prima: Primera Revista Independiente de Terapia Ocupacional en Argentina. 2000; 4(1):5-8. 
2001

1. Lopes RE, Barros DD, Malfitano APS, Galvani D, Galluzzi AM. Terapia ocupacional no território: as crianças e os adolescentes da unidade do Brás: Movimento de luta por moradia urbana. Cad. de Ter. Ocup. UFSCar. 2001; 9(1):30-49.

2. Lopes RE, Barros, Denise D, Malfitano APS, Galvani D. O espaço do brincante na experiência do Projeto Casarão. Rev. Ter. Ocup. Univ. 2002 Dez.;12(1/3):48-51.

3. Lopes RE, Barros DD, Galvani D, Malfitano APS, Galluzzi AM. Projeto Casarão: parceria no dia-a-dia. O COFFITO. 2001 Dez.;13:10-5.

4. Lopes RE, Barros DD, Galvani D, Malfitano APS, Galluzzi AM, Galheigo SM, Reis, TAM. Projeto Metuia: o terapeuta ocupacional no campo social. O COFFITO. 2001 Dez.;13:30-3.

2002

1. Oliver FC, Tissi MC, Aoki M, Vargem EF, Ferreira TG. Oficina de trabalho: sociabilidade ou geração de renda? Rev. Ter. Ocup. Univ. 2002 Set./Dez.;13(3):87-94.

2. Barros DD, Ghirardi MIG, Lopes RE. Terapia ocupacional social. Rev. Ter. Ocup. Univ. 2002 Set./Dez.;13(3):95-103.

3. Lopes RE, Galvani D, Barros DD, Malfitano APS, Barros G. O vídeo como elemento comunicativo no trabalho comunitário. Cad. de Ter. Ocup. UFSCar. 2002; 10(1):61-7.

4. Lopes RE, Barros DD, Galheigo SM. Projeto Metuia: Terapia Ocupacional no Campo Social. O Mundo da Saúde. 2002 Jul./Set.;26(3):365-9.

5. Lopes RE, Barros DD, Malfitano APS, Galvani D. Histórias de vida: a ampliação de redes sociais de suporte de crianças em uma experiência de trabalho comunitário. O Mundo da Saúde. 2002 Jul./Set.;26(3):426434.

6. El-Khatib U. Crianças e adolescentes em situação de risco pessoal e social: que problema é esse. Cad. de Ter. Ocup. UFSCar. 2002;9(2):119.

\section{3}

1. Galheigo SM. O abrigo para crianças e adolescentes: considerações acerca do papel do terapeuta ocupacional . Rev. Ter. Ocup. Univ. 2003 Maio/Ago.;14(2):87-94. 
2. Galheigo SM. O cotidiano na terapia ocupacional: cultura, subjetividade e contexto histórico-social -. Rev. Ter. Ocup. Univ. 2003 Set./Dez.;14(3):104-8.

3. Lopes RE, Borba PLO, Reis TA. M. Um olhar sobre as trajetórias, percursos e histórias de mulheres em situação de rua. CAD. de Ter. Ocup. UFSCar. 2003;11(1):38-53.

\section{4}

1. Terapia ocupacional social: o caminho se faz ao caminhar - D.D. Barros. Rev. Ter. Ocup. Univ. 2004 Set./Dez.; vol. 15 n.3, p. 90- 97,2004

2. Ghirardi MIG. Trabalho e deficiência: as cooperativas como estratégias de inclusão social. Rev. Ter. Ocup. Univ. 2004Maio/Ago.;15(2): 49-54.

3. Malfitano APS, Lopes RE. Apontamentos de campo acerca de uma experiência de educação não-formal com crianças e adolescentes em situação de rua. Série-estudos. 2004;17(17):29-42.

4. Almeida MM. O jornal e o vídeo como meio de expressão de jovens internados na Unidade Educacional da FEBEM de Ribeirão Preto. Rev. Ter. Ocup. Univ. 2004 Jan./Abr.;15(1):33-8.

\section{5}

1. Malfitano A. P. S. Campos e núcleos de intervenção na terapia ocupacional social -. Rev. Ter. Ocup. Univ. 2005 Jan./Abr.;16(1):1-8.

2. El-Khatib $\mathrm{U}, \mathrm{Um}$ estudo acerca da passagem de crianças e adolescentes pelo judiciário no município de São Carlos. Cad. de Ter. Ocup. UFSCar. 2005;13(1):19-37.

3. Ghirardi MIG, Barros DD, Lopes S, Galvani D. Vida na rua e cooperativismo:transitando pela produção de valores. Interface 601 Comunic, Saúde, Educ. 2005 Set./Dez.;9(18):601-10.

4. Lopes RE, Palma AM, Reis TAM. A experimentação teórico-prática do aluno de terapia ocupacional no campo social: uma vivência com a população em situação de rua. Rev. Ter. Ocup. Univ. 2005 Maio/Ago.;16(2):54-61.

5. Malfitano APS, Lopes RE. Crianças e adolescentes, a rua e o abrigo: desafios da ressignificação de Sentidos numa Experiência de Educação Não-Formal. In: Park MB, Fernandes RS, organizadores. Educação nãoformal: contextos, percursos e sujeitos. Campinas e Holambra: Unicamp/Centro de Memória. 2005 Set.;1:241-60.

6. Vecchia T, Barros DD, Sato M. Jovens do bairro da Pedra do Papagaio: notas sobre uma oficina de fotografia Jovens do bairro da Pedra do 
Papagaio: notas sobre uma oficina de fotografia - Projeto Casa Rosa. Imaginário, LABI-USP. 2005;11(11):335-61.

7. Feriotti M.L. Colcha de retalhos: costurando diferenças e tecendo cidadania. In: Pádua EMM, Magalhães LV, organizadores. Casos, memórias e vivencias em terapia ocupacional. Campinas: Papirus; 2005. p. $33-45$.

8. Galheigo SM. O social: idas e vindas de um campo de ação em Terapia Ocupacional. In: Pádua EMM, Magalhães LV, organizadores. Terapia Ocupacional Teoria e Prática. $3^{\text {a }}$ ed. Campinas: Papirus; 2005. p. 29-46.

9. Galheigo SM. Quatro grupos, vivências, fragmentos de histórias: jovens em tempos de violência. In: Pádua EM, Magalhães LV, organizadores. Casos, Memórias e Vivências em Terapia Ocupacional. Campinas: Papirus; 2005. v. 1, p. 115-144.

\section{6}

1. Lopes RE, Malfitano APS, Borba PLO. O processo de criação de vínculo entre adolescentes em situação de rua e operadores sociais: compartilhar confiança e saberes. Quaestio (UNISO). 2006;8(1): 121-31, 2006.

2. Lopes RE, Malfitano APS, Silva CR, Borba PLO, Takeiti BA, Garcia DB, Furlan PG. Terapia Ocupacional Social e a Infância e a Juventude Pobres: Experiências do Núcleo UFSCar do Projeto METUIA. CAD. de Ter. Ocup. UFSCar. 2006;14(1):5-14.

3. Malfitano APS, Braga IF, Silva KGS, Mota NG. A promoção de direitos e crianças e adolescentes em situação de vulnerabilidade social: oficina de brincadeiras como recurso. Cad. de Ter. Ocup. UFSCar. 2006 MÊS;14(2):103-10.

4. Lopes RE, Malfitano APS. Ação social e intersetorialidade: relato de uma experiência na interface entre saúde, educação e cultura. Revista Interface - Comunic, Saúde, Educ, 2006 Jul./Dez.;10(20):505-15.

5. Rocha PR. Estação cidadania - uma experiência no atendimento de crianças e adolescentes em situação de risco. Rev. Ter. Ocup. Univ. 2006 Jan./Abr.;17(1):6.

6. Barros DD, Galvani D, Almeida MC, Sato M, Reis TAM. Perfil dos freqüentadores da casa de convivência e centro de serviços Associação Minha Rua Minha Casa entre 2002 e 2003. Rev. Ter. Ocup. Univ. 2006 Jan./Abr.;17(1):48-56. 
1. Barros DD, Lopes RE, Galheigo SM. Terapia ocupacional social: concepções e perspectivas. In: Cavalcante A, Galvão C, organizadores. Terapia Ocupacional: fundamentação e prática. Rio de Janeiro: Guanabara Koogan; 2007. p. 347-53.

2. Barros DD, Lopes RE, Galheigo SM. Novos espaços, novos sujeitos: a terapia ocupacional no trabalho territorial e comunitário. In: Cavalcante A, Galvão C, organizadores. Terapia Ocupacional: fundamentação e prática. Rio de Janeiro: Guanabara Koogan; 2007. p. 354-63.

3. Galvani D, Barros DD, Lopes RE, Reis TAM. Terapéutica Ocupacional en el Campo Social: construyendo caminos y rescatando proyectos con adultos que viven en calles. In: Paganizzi L, organizador. Terapia ocupacional psicosocial: escenarios clínicos y comunitarios. Buenos Aires: Polemos; 2007. p. 203-8.

4. Barros DD, Ghirardi, Garcez MI, Lopes RE. Terapia ocupacional social: una perspectiva sociohistórica. In: Kronenberg F, Algado SS, Pollard N, orgaanizadores. Terapia ocupacional sin fronteras: aprendiendo del espíritu de supervivientes. Madri: Editorial Médica Panamericana; 2007. p. 141-13. v.1.

5. Barros DD, Lopes RE, Galheigo SM, Galvani D. El Proyecto Metuia en Brasil: ideas y acciones que nos unen. In: Kronenberg F, Algado SS, Pollard N, organizadores. Terapia ocupacional sin fronteras: aprendiendo del espíritu de supervivientes. Madri: Editorial Médica Panamericana; 2007. p. 392-403. v. 1.

6. Lopes RE, Malfitano APS. Abrigo. In: Park MB, Fernandes RS, Carnicel $A$, organizadores. Palavras-chave em educação não-formal. Holambra e Campinas: Unicamp/Centro de Memória da Unicamp. 2007 Set.;1:55-6.

7. Lopes RE, Malfitano APS. Centro Comunitário. In: Park MB, Fernandes RS, Carnicel A, organizadores. Palavras-chave em educação nãoformal. Holambra e Campinas: Unicamp/Centro de Memória da Unicamp. 2007 Set.; 1: 79-80.

8. Lopes RE, Malfitano APS. Políticas Sociais. In: Park MB, Fernandes RS, Carnicel A, organizadores. Palavras-chave em educação não-formal. Holambra e Campinas: Unicamp/Centro de Memória da Unicamp. 2007 Set.; 1: 233-4.

9. Lopes RE. Rede social de suporte. In: Park MB, Fernandes RS, Carnicel A, organizadores. Palavras-chave em educação não-formal. Holambra e Campinas: Unicamp/Centro de Memória da Unicamp. 2007 Set.; 1:25950. 
2008

1. Galvani D. Pessoas em situação de rua na cidade de São Paulo: itinerários e estratégias na construção de redes sociais e identidades. [dissertação] São Paulo (SP): Faculdade de Medicina da Universidade de São Paulo; 2008.

2. Lopes RE, Malfitano APS, Silva CR, Borba PO, Takeiti BA. A Formação de Recursos Humanos no Território: a Experiência do Núcleo UFSCar do Projeto METUIA no Desenvolvimento de Extensão, Ensino e Pesquisa. XI Encontro Nacional de Docentes de Terapia Ocupacional. 2008; São Paulo. Anais do XI Encontro Nacional de Docentes de Terapia Ocupacional. São Paulo: Revista de Terapia Ocupacional da Universidade de São Paulo; 2008. v. 19. p. 119-125.

3. Lopes RE, Barros DD, Oliver FC, Galheigo SM. Terapia Ocupacional e Educação no Campo Social. XI Encontro Nacional de Docentes de Terapia Ocupacional. 2008; São Paulo. Anais do XI Encontro Nacional de Docentes de Terapia Ocupacional. São Paulo: Revista de Terapia Ocupacional da Universidade de São Paulo; 2008. v. 19. p. 48-49.

4. Lopes RE, Adorno RCF, Malfitano APS, Takeiti BA, Silva CR, Borba PLO. Juventude pobre, violência e cidadania. Saúde e Sociedade. 2008;17:63-76. 


\section{Referências}

1. Emmel MLG, Lancman S. Quem são nossos mestres e doutores?: O avanço da capacitação docente em terapia ocupacional no Brasil. Cad. Ter. Ocup. UFSCa. 1998;7(1):29-38.

2. Lancman S. A influência da capacitação dos terapeutas ocupacionais no processo de constituição da profissão no Brasil. Cad. Ter. Ocup. UFSCar. 1998;7(2):49-57.

3. Instituto Nacional de Estudos e Pesquisas Anísio Teixeira (INEP) [homepage da Internet] [acessado em 2007 Set.]. Disponível em http://www.educacaosuperior.inep.gov.br/funcional/lista cursos.asp.

4. Haddad AE, Pierantoni CR, Ristoff D, Xavier IM, Giolo J, Silva LB. A trajetória dos cursos de graduação na saúde: 1991- 2004. Brasília: Inep/MEC; 2006.

5. Hollanda AB. Dicionário Aurélio da língua português. São Paulo: Perspectiva; 1986. p.142.

6. Bourdieu P. Questões de sociologia. Rio de Janeiro: Marco Zero; 1983.

7. Bourdieu P. Coisas Ditas. São Paulo: Brasiliense; 1990.

8. Bourdieu P. A Economia das trocas simbólicas. São Paulo: Perspectiva; 2003.

9. Bourdieu P. Razões práticas: sobre a teoria da ação. $6^{a}$ ed. Campinas: Papirus; 2005.

10. Bourdieu apud Wacquant L. [homepage da Internet]. [acessado em agosto 2008] Disponível em: http://sociology.berkeley.edu/faculty/wacquant/wacquant pdf/ESCLARECE ROHABITUS.pdf.

11. Bourdieu P. Questões de sociologia. Rio de Janeiro: Marco Zero; 1983. p. 90.

12. Barros DD, Lopes RE, Galheigo SM. Terapia ocupacional social: concepções e perspectivas. In: Cavalcante A, Galvão C, organizadores. Terapia Ocupacional: fundamentação e prática. Rio de Janeiro: Guanabara Koogan; 2007. p. 347-53.

13. Castel R. As transformações da questão social. In Belfiore- Wanderle.y M, Bógus L, Yazbek MC, organizadores. Desigualdade e a questão social. São Paulo: Educ; 1997.

14. Castel R. As transformações da questão social. In Belfiore- Wanderle.y M, Bógus L, Yazbek MC, organizadores. Desigualdade e a questão social. São Paulo: Educ; 1997. p. 164.

15. Noronha GV, Rocha LGBSP. Elias e Bourdieu: para uma sociologia histórica ou seria uma história sociológica? Rev. Habitus, vol. 5, n 1, 2007. [acessado em agosto de 2008] Disponível em www.habitus.ifcs.ufrj.br.

16. Elias N. A sociedade dos indivíduos. Rio de Janeiro: Jorge Zahar; 1994. p. 36.

17. Elias N. A sociedade dos indivíduos. Rio de Janeiro: Jorge Zahar; 1994. p. 77.

18. Instituto Nacional de Estudos e Pesquisas Educacionais Anísio Teixeira (INEP) - http://www.educacaosuperior.inep.gov.br/funcional/lista_cursos.asp [homepage da Internet] [acessado em set. 2007]. 
19. Barros DD, Oliver FC. Contribuições para a discussão do Qualis de terapia ocupacional no Brasil. Rev. Ter. Ocup. Univ. 2003 Maio/Ago.;14(2):52-63.

20. Bittencourt RCB, Faria I, Vestane S, Medeiros OM, Correa MR. Meninas de Minas. [CD-ROM]. Anais X Congresso Brasileiro de Terapia Ocupacional; 2007 Maio 15-18; Goiânia, Goiás; 2007.

21. Krug JC, Hoffmann DS, Peruzzolo DL. Atividade de construção de brinquedos de argila e sucata no processo de individuação, conscientização e auto-cuidado [CD-ROM]. Anais do X Congresso Brasileiro de Terapia Ocupacional; 2007 Maio 15-18; Goiânia, Goiás; 2007.

22. Carvalho RH, Silva ALJ. A terapia ocupacional em comissão técnica de classificação: uma proposta de avaliação terapêutica ocupacional. Anais do VII Congresso Brasileiro de Terapia Ocupacional; 2001 Out. 2-5; Porto Alegre, Rio Grande do Sul; 2001. p 189.

23. Cruz FS, Menta SA. Avaliação de qualidade de vida do povo Kadiwéu de Mato Grosso do Sul, Brasil... Anais do VIII Congresso de Terapia Ocupacional; 2003 Jun. 2-6; Foz do Iguaçu, Paraná; 2003.

24. Dorneles P. Projeto prazer sem risco [CD-ROM]. Anais do IX Congresso Brasileiro de Terapia Ocupacional; 2005 Set. 27-30; Recife, Pernambuco; 2005.

25. Poltronieri BC, Santos ZNL. A terapia ocupacional na educação popular em comunidades rurais ribeirinhas de São Domingos do Capim [CD-ROM]. Anais do X Congresso Brasileiro de Terapia Ocupacional; 2007 Maio 15-18; Goiânia, Goiás; 2007.

26. Malfitano, APS, Leonardi K, Aoki M, Oliver FC. Estudo de caso: território como espaço terapêutico uma abordagem em reabilitação. Anais do $7^{\circ}$ Congresso Brasileiro de Terapia Ocupacional. 2001 Out. 2-5; Porto Alegre, Rio Grande do Sul; 2001. p. 99.

27. Escorel; 1999. p. 23- 81. Apud Galheigo SM. O social: idas e vindas de um campo de ação em terapia ocupacional. In: Pádua EMM, Magalhães LV, organizadores. Terapia ocupacional. Campinas: Papirus; 2005. p. 29-46.

28. Rezende A. Grupo Carpe Diem: a utilização da dança como processo de inclusão social com idosos do núcleo intergeracional de convivência. Anais do VII Congresso Brasileiro de Terapia Ocupacional. 2001 Out. 2-5; Porto Alegre. Porto Alegre: Instituto Porto Alegre; 2001. p. 107.

29. Oliveira IBS, Seabra AD, Ponte ABM, Araújo JS, Araújo LS, Bentes SLT. Encadernação, V.R.L. Brinquedoteca: um espaço de exercício da cidadania infantil. Anais do VII Congresso Brasileiro de Terapia Ocupacional. 2001 Out. 2-5; Porto Alegre. Porto Alegre: Instituto Porto Alegre; 2001. p. 69.

30. Costa CO, Dorneles P. Galpão de reciclagem: buscando e entendendo a inclusão social através do trabalho com lixo [CD-ROM]. Anais do IX Congresso Brasileiro de Terapia Ocupacional; 2005 Set. 27-30; Recife, Pernambuco; 2005.

31. Antunes DC; Borini MLO. Envelhecimento compartilhado: grupos comunitários - uma atuação possível em Terapia Ocupacional. Anais do VII Congresso Brasileiro de Terapia Ocupacional; 2001 Out. 2-5; Porto Alegre, Rio Grande do Sul. Porto Alegre: Instituto Porto Alegre; 2001. p. 94. [Pôster].

32. Galheigo SM. Educação e Trabalho: velhos dilemas, novos rumos nos programas de profissionalização para adolescentes. Anais do VI Congresso Brasileiro, IV Simpósio Latino Americano de Terapia Ocupacional. 1997 
Out. 28-31; Belo Horizonte. Belo Horizonte: Associação dos Terapeutas Ocupacionais de Minas Gerais; 1997. v. 1. p. 158-60.

33. VI Congresso Brasileiro de Terapia Ocupacional; 1999 Set. 28-Out. 01; Águas de Lindóia, São Paulo. Programas e Resumos. p. 8 e 14.

34. Falcão IV. Perspectivas da evolução profissional através dos congressos brasileiros de terapia ocupacional. Anais do VIII Congresso Brasileiro de Terapia Ocupacional, V Congresso Latino Americano de Terapia Ocupacional. 2003 Jun. 2-6; Foz do Iguaçu, Paraná; 2003. p. 57.

35. Nicolau SM. Terapia ocupacional e economia solidária: uma parceria promissora. Anais do $7^{\circ}$ Congresso Brasileiro de Terapia Ocupacional. 2001 Out. 2-5; Porto Alegre. Porto Alegre: Instituto Porto Alegre; 2001. p. 36.

36. Leão ACA, Cabral CB. Experiências de terapia ocupacional no processo de ressocialização de detentos [CD-ROM]. Anais do X Congresso Brasileiro de Terapia Ocupacional. 2007 Maio 15-18; Goiânia. Goiás; 2007.

37. Gerassi MI. Resignificando identidades: a minha trajetória no campo social. [CD-ROM]. Anais do X Congresso Brasileiro de Terapia Ocupacional. 2007 Maio 15-18; Goiânia. Goiás; 2007.

38. Botteon LM, Cunha CD. Terapia ocupacional social: exclusão como marco característico da demanda. Anais do $\mathrm{X}$ Congresso Brasileiro de Terapia Ocupacional. 2007 Maio 15-18; Goiânia. Goiás; 2007.

39. Lopes RE, Malfitano APS, Borba, PLO. Problematizando a atuação do terapeuta ocupacional nas organizações não-governamentais. [CD-ROM]. Anais do X Congresso Brasileiro de Terapia Ocupacional. 2007 Maio 15-18; Goiânia. Goiás; 2007.

40. Achê $P$, Oliveira AS. A ocupação no MST: percepção e compreensão dos sem-terras - um olhar da terapia ocupacional. [CD-ROM]. Anais do X Congresso Brasileiro de Terapia Ocupacional. 2007 Maio 15-18; Goiânia. Goiás; 2007.

41. Druck G, Filgueiras L. Política social focalizada e ajuste fiscal: as duas faces do governo Lula. Rev. Katálisis. 2007 Jan./Jun.;10(1): 24-34.

42. Bourdieu P. A Economia das trocas simbólicas. São Paulo: Perspectiva; 2003. p. 190.

43. Galheigo SM. Repensando o lugar do social: a constituição de um campo de conhecimento em terapia ocupacional. Programas e Resumos do VI Congresso Brasileiro de Terapia Ocupacional. 1999 Set. 28-Out. 01; Águas de Lindóia, São Paulo: 1999.

44. Galheigo SM. Repensando o lugar do social: a constituição de um campo de conhecimento em terapia ocupacional. Programas e Resumos do VI Congresso Brasileiro de Terapia Ocupacional. 1999 Set. 28-Out. 01; Águas de Lindóia, São Paulo: 1999. p. 4.

45. Galheigo SM. O social: idas e vindas de um campo de ação em terapia ocupacional. In: Pádua EMM, Magalhães LV, organizadores. Terapia ocupacional. Campinas: Papirus; 2005. p. 29-46.

46. Galheigo SM. O social: idas e vindas de um campo de ação em terapia ocupacional. In: Pádua EMM, Magalhães LV, organizadores. Terapia ocupacional. Campinas: Papirus; 2005. p. 33.

47. Barros DD. Operadores de saúde na área social. Rev. Ter. Ocup. Univ. 1990 Ago.; 1(1):13. 
48. El-Khatib U. Quando se trata de investigar "crianças e adolescentes em situação de risco pessoal e social"... Cad. de Ter. Ocup. UFSCar. 1998; $7(1): 1-13$.

49. Galheigo SM. Educação e Trabalho: velhos dilemas, novos rumos nos programas de profissionalização para adolescentes. Anais do VI Congresso Brasileiro, IV Simpósio Latino Americano de Terapia Ocupacional. 1997 Out. 28-31; Belo Horizonte. Belo Horizonte: Associação dos Terapeutas Ocupacionais de Minas Gerais; 1997. v. 1. p. 49.

50. Barros DD, Lopes RE, Galheigo SM. Projeto Metuia - terapia ocupacional no campo social. Rev. O Mundo da Saúde. São Paulo. 2002 Jul./Set.;26(3).

51. Castel R. Da indigência à exclusão, a desfiliação. Precariedade do trabalho e vulnerabilidade relacional. In: Lancetti A, organizador. Saúde Loucura, n.4. São Paulo: Hucitec; 1994. p.21-48.

52. Castel R. As transformações da questão social. In Belfiore- Wanderle.y M, Bógus L, Yazbek MC, organizadores. Desigualdade e a questão social. São Paulo: Educ; 1997.

53. Castel R. As metamorfoses da questão social. Petrópolis: Vozes; 2005.

54. Barros DD, Ghirardi MIG, Lopes RE. Terapia ocupacional e sociedade. Rev. Ter. Ocup. Univ. 1999 Maio/Dez.;10(2/3):69-74.

55. Balaguer AL, Oliveira MC. Trabalhos com enfoque na comunidade: estratégias e dificuldades de ação na ótica da terapia ocupacional no campo social. Anais do VI Congresso Norte Nordeste de Terapia Ocupacional. 2006; Maceió. Terapia Ocupacional "Da Clínica ao Social". Maceió: ATOAL, 2006. v. 1. p. $s / n-s / n$.

56. Galvani D, Barros DD. Construção de projetos como metodologia de atenção a pessoas em processos de ruptura das redes sociais de suporte: um estudo de caso. Anais do VI Congresso Norte Nordeste de Terapia Ocupacional, 2006, Maceió. Terapia Ocupacional "Da Clínica ao Social". Maceio: ATOAL, 2006. v. 1. p. s/n-s/n.

57. Lisboa FP, Cunha GC, Balaguer AL, Oliveira MC. Projeto torres; terapia ocupacional na rádio em redes sociais. Anais do VI Congresso Norte Nordeste de Terapia Ocupacional, 2006, Maceió. Terapia Ocupacional "Da Clínica ao Social". Maceió: ATOAL, 2006. v. 1. p. s/n-s/n.

58. Galheigo SM. Young people, Subjectivity and Social Rights. 13th World Congress of Occupational Therapists. [CD-ROM]. Abstract Book Stockholm WFOT; 2002. Stockholm: WFOT and Swedish Association of Occupational Therapists; 2002. v. 1.

59. Galheigo SM. Cultural identity and diversity in late modernity: the local and the global for community-based juvenile groups. 14th Congress of the World Federation of Occupational Therapists; 2006; Sydney. Abstracts - 14th Congress of the World Federation of Occupational Therapists. Australia: WFOT/OT Austrália; 2006.

60. Lopes RE, Malfitano APS, Silva CR, Borba PLO, Garcia DB, Furlan PG. Childhood and youth in extreme social vulnerability: experiences in social occupational therapy for increasing supporting social nets. 14th Congress of the World Federation of Occupational Therapists. 2006; Sidney, Austrália; World Federation of Occupational Therapists - WFOT, 2006. v. 1.

61. Reis TAM, Galvani D, Barros DD, Lopes RE. Núcleo Produtivo - lados del trabajo con población adulta de calles en São Paulo - Brasil. Anais do VI 
Congreso Argentino de Terapia Ocupacional:controversias al sur del continente: diversidad, integración y complejidad; 2003; Buenos Aires; Associación de Terapistas Ocupacionales; 2003.

62. Lopes RE, Barros DD, Galvani D, Malfitano APS, Barros GD. O vídeo como elemento comunicativo no trabalho comunitário:o Projeto Casarão. Anais do I Congresso Brasileiro de Extensão Universitária. 2002; João Pessoa, ParaíbaAnais. João Pessoa: Universidade Federal da Paraíba / Pró-Reitoria de Extensão e Assuntos Comunitários; 2002. v. 1.

63. Barros DD, Lopes RE, Reis, TAM, Galvani D, Malfitano AAS. População adulta em situação de rua: resgatando percursos e construindo projetos: a experiência do Projeto Metuia. Anais do I Congresso Brasileiro de Extensão Universitária. 2002; João Pessoa, ParaíbaAnais. João Pessoa: Universidade Federal da Paraíba / Pró-Reitoria de Extensão e Assuntos Comunitários; 2002. v. 1.

64. Lopes RE, Malfitano APS, Borba, PLO. A escolha pela saída da rua: desafios de um abrigo com crianças e adolescentes em situação de rua. Anais do II Congresso Brasileiro de Extensão Universitária e III Encontro Nacional de Avaliação Institucional de Extensão Universitária. 2004; Belo Horizonte, Minas Geraes; Fórum de Extensão da IES Brasileiras / Universidade Federal de Minas Gerais; 2004.

65. Galheigo SM, Takeiti B. Adolescência, reciprocidade e ação territorial: pensando estratégias de ação na prevenção da violência. [CD-ROM]. Resumos I Simpósio Internacional do Adolescente - Adolescência hoje: desafios, práticas e políticas. 2005; São Paulo; 2005.

66. Malfitano APS, Lopes RE. A busca de métodos para a construção de um paradigma de casa com crianças e adolescentes em situação de rua - 0 abrigo AFAGAI. V Seminário de Metodologia para Projetos de Extensão. 2003; João Pessoa, Paraíba. João Pessoa: UFPB/PRAC - V SEMPE; 2003.

67. Barros DD, Lopes RE, Galheigo SM. Terapia ocupacional social: concepções e perspectivas. In: Cavalcante A, Galvão C, organizadores. Terapia Ocupacional: fundamentação e prática. Rio de Janeiro: Guanabara Koogan; 2007. p. 352.

68. Barros DD. Desafios para uma formação de profissionais de saúde sensíveis à diversidade. [CD-ROM]. X Congresso Brasileiro de Terapia Ocupacional. 2007.

69. Galheigo, SM. Campo social e terapia ocupacional: grandes temáticas contemporâneas em debate. Anais do X Congresso Brasileiro de Terapia Ocupacional; 2007 Maio 15-18; Goiânia, Goiás; 2007. p.4.

70. Barros DD. O debate em torno da questão social e a terapia ocupacional. Mimeo, p. 4. 